\title{
5. Nietzsche, el concepto de tiempo y la historiografía
}

\author{
Creemos que nuestro presente se apoya en intenciones profundas, \\ necesidades estables; \\ pedimos a los historiadores que nos convenzan de ello. \\ Pero el verdadero sentido histórico reconoce que vivimos, \\ sin referencias ni coordenadas originarias, \\ en miríadas de acontecimientos perdidos
}

(Foucault, 2008, pp. 50-51).

Se trata de hacer de la historia un uso que la libere para siempre del modelo, a la vez metafísico y antropológico, de la memoria. Se trata de hacer de la historia una contra-memoria, $y$ de desplegar en ella, por consiguiente, una forma totalmente distinta de tiempo

(Foucault, 1979, p. 25).

En este quinto capítulo se intentarán reseñar algunas discusiones sobre la pertinencia del pensamiento de Nietzsche en la historiografía y la Teoría de la Historia ${ }^{78}$. En una primera parte, guiados por las ideas de F. R. Ankersmit y Hayden White, se discutirán algunos aspectos de la narrativa en la historia, sobre todo lo concerniente al carácter histórico de nuestra idea de tiempo, anticipando algunas estrategias narrativas y protocolos de prefiguración tropológica exhibidos en una obra como Así habló Zaratustra.

En segundo lugar, un par de artículos de Thomas Brobjer y compilaciones como Nietzsche on Time and History (Dries, 2008), entre otros materiales, permitirán valorar con más detalle la relación de Nietzsche con la historia y los métodos históricos,

78 Para una relación más exhaustiva entre Nietzsche y la Historia, a partir de un análisis riguroso de la Segunda Consideración Intempestiva (Nietzsche, 2000), ver el primer capítulo del trabajo de Roch Ch. Little. 
siempre a partir de su crítica al concepto moderno de "tiempo". Luego, en una tercera parte, se hará una aproximación a la idea de "nuevas temporalidades" según intuiciones de pensadores y teóricos como Robin Small, Michel Foucault y Keith Jenkins.

Tanto la posibilidad de una deconstrucción de la historia como una definición experimental de la posmodernidad como transmutación de los valores modernos serán abordados en este acápite. Asimismo, el trabajo de David Wood The Decosntruction of Time (Wood, 2001) iluminará aspectos precisos de la pesquisa. Al final, en una cuarta parte, partiendo del clásico estudio de Carl Pletsch sobre la Historia y la filosofía del tiempo en Nietzsche (Pletsch, 1977), se trabajará la idea de devenir y temporalidad del Aión según Gilles Deleuze y Félix Guattari. Aparecerán consideraciones sobre la memoria corta tipo rizoma, las multiplicidades que escapan a la captura de grandes referentes históricos y la forma como el eterno retorno es escenificado por Nietzsche, todo al hacer una revisión de tres obras que abordan específicamente aspectos narrativos y de construcción de la temporalidad en Así habló Zaratustra (Rosen, 1995; Seung, 2005; Loeb, 2010).

\subsection{FILOSOFÍA NARRATIVISTA DE LA HISTORIA}

El teórico de la historia Frank Ankersmit, nacido en Holanda (1945), ha planteado en Historia y tropología una idea que servirá de hilo conductor en este apartado: [tesis sobre la filosofía narrativista: 1.4.1] "El tiempo histórico es una invención relativamente reciente y en gran medida artificial de la civilización occidental. Es una noción cultural, no filosófica. Por lo tanto, basar la narrativa en el concepto de tiempo es construir en arenas movedizas" (Ankersmit, 2004, p. 72, subrayado fuera del texto).

Comenzar historizando la misma noción de tiempo histórico es un gesto ejemplar de genealogía nietzscheana. Traduciendo muchos pasajes de los anteriores capítulos de este Tempus Ex Machina en clave historiográfica, se sostiene que tal ha sido justamente el punto de partida de las aseveraciones: constatar la "artificialidad" de la idea moderna de tiempo, vivida y expresada a través de la narrativa de una obra como Así habló Zaratustra.

"Construir sobre arenas movedizas" es una imagen que muestra gran empatía con el impulso metafórico intentado a lo largo del documento. Allí donde tales comparaciones sirven menos como modalidades solo expresivas que como dispositivos de creación cognitivos. Es decir, el tejimiento metafórico del relato histórico implica directamente los modos de comprenderlo, asignando, por ejemplo, posibilidades de espacio-tiempo que sirven de moldes de legibilización para los acontecimientos allí contenidos.

De allí que sea posible hablar de "temporalidades" construidas en el interior y como consecuencia de las elecciones relatológicas que hace el historiador, de la misma forma que se fabrican "túneles de realidad" que dan consistencia a esquemas de espacialización y ambientación de los "hechos". 
Este tipo de sensibilidad será explorada de la mano de Hayden White y Frank Ankersmit, quienes han extraído las consecuencias epistemológicas de una consideración profunda de las técnicas narrativas a las que ineludiblemente se ve enfrentado el investigador, a la vez que han denunciado como deleznables los intentos de fabricar andamiajes conceptuales de tipo científico en la forma de dar cuenta de los eventos del pasado.

De acuerdo con estas ideas, F. R. Ankersmit define la naturaleza del conocimiento histórico en estos términos: "la historia es la primera de las disciplinas que vienen a la mente si pensamos en las que pretenden ofrecer una representación verídica de una realidad compleja por medio de un texto complejo" (Ankersmit, 2004, p. 15). Tal "representación verídica" va a ser el punto de cuestionamiento general en su teoría narrativista de la historia.

Deudor explícito de la teoría o "metateoría" histórica de Hayden White, Ankersmit se muestra muy interesado en las formas como damos cuenta de unos eventos del pasado según estructuras narrativas que serán siempre tropológicas, figurativas, retóricas. Se sostiene que la filosofía de la historia ha descuidado estos aspectos propiamente escriturales en provecho de una visión que privilegia el trabajo investigativo, como si aún se sostuviera algún carácter "objetivo" o "científico" para el tipo de representación que fraguan los historiadores. Esa "pretensión" define lo que se Ankersmit va a llamar "historismo" y que aquí se considera no muy lejos de la historia que denunció F. Nietzsche en su segunda intempestiva como responsable de un empobrecimiento de la vida, una visión excesivamente erudita que no duda en calificar de "enfermedad" (Nietzsche, 2000, p. 33).

Partiendo de Hayden White, la clave es resaltar el artificio narrativo como constitutivo de la realidad histórica, y no como reflejo más o menos fiel de los eventos del pasado. Ya el temprano opúsculo de Nietzsche Sobre verdad y mentira en sentido extramoral (Nietzsche, 2002) alertado sobre la naturaleza metafórica y tropológica de eso llamado "verdad", y mucho más si se enuncia como alguna suerte de "verdad" histórica.

En este campo específico la "verdad" es un efecto y no un dato ontológico, como se sostiene en "Historia y Tropología": "contar una historia (o escribir la historia) es una construcción que imponemos a los hechos" (Ankersmit, 2004, p. 20). Esta imposición pretende naturalizarse para una Teoría de la Historia que aún ve en esta una posibilidad de acercamiento "neutral" al pasado. El joven Nietzsche que ya en la década de los setenta del siglo XIX escribía el opúsculo que se mencionó, prohibía tales ingenuidades epistemológicas, circunscribiendo la visión del mundo a las formas lingüísticas usadas para configurarlo.

Nietzsche se aparta de manera definitiva de una visión del lenguaje como instancia de descripción de alguna realidad intrínseca o con significado en las cosas mismas, y más bien pasa a considerar las formas como esa "realidad", especialmente desde el punto de vista "histórico", es un resultado del uso de técnicas de modelización del relato que deben ser analizadas. 
Siguiendo las huellas del archi-clásico estudio sobre la imaginación histórica en la Europa del siglo XIX “Metahistoria”, publicado por vez primera en 1973, y como acechando una presa según sucesivos pasos que secuenciados e inscritos en una trama son el relato mismo, se cita la intuición básica de Hayden White:

A través del develamiento de la base lingüística sobre la cual se constituyó determinada idea de la historia, he intentado establecer la naturaleza ineluctablemente poética de la obra histórica y especificar el elemento prefigurativo de cualquier relato histórico, que tácitamente sanciona sus conceptos teóricos (White, 2001, p. 10).

Las consecuencias políticas de este enfoque, incluso en términos de geopolíticas de conocimiento, son abrumadoras: "es posible ver la consciencia histórica como un prejuicio específicamente occidental por medio del cual se puede fundamentar en forma retroactiva la presunta superioridad de la sociedad industrial moderna" (White, 2001, p. 14). Tal afirmación había sido anticipada por Nietzsche en su segunda consideración intempestiva al calificar de "enfermedad" la hipertrofia historicista a la sazón en boga, con lo que las pretensiones de neutralidad y cientificidad de las narrativas del pasado exhibían su lado oscuro, su inconsciente poblado de monstruos y raras o paradójicas cronologías.

Para el autor de "Las ventajas e inconvenientes de la Historia para la vida" el criterio rector es la potenciación de una "vida" que a nivel colectivo también exige alguna dosis de "olvido" como fármakon para hacer soportable las exageraciones hiper-eruditas y francamente farragosas de un positivismo historiográfico en trance de consolidación. Desposicionar la supremacía sentida como auto-evidente de la historia científica va a ser no solo un conato innegable para Nietzsche, sino a la postre para los historiadores, filósofos y estudiosos culturales abusiva, estratégica o acomodaticiamente etiquetados como "posmodernos"79.

Si es verdad que para los relatos históricos "su categorización como modelos de la narración y de la conceptualización históricas depende, finalmente, de la naturaleza preconceptual y específicamente poética de sus puntos de vista sobre la historia y sus procesos", entonces puede sugerirse una mirada a la estructura narrativa de una obrabisagra como Así habló Zaratustra.

Se dice "bisagra" dada la perplejidad que asalta a quienes han intentado clasificar este texto del lado de la filosofía, de la poesía, de la narrativa propiamente literaria, o incluso de la autobiografía figurada. Las aventuras de Zaratustra se inscriben en el umbral de tales pretensiones taxonómicas. Para $\mathrm{H}$. White la explicación histórica deriva de tipos de tramado como el llamado "romance", sobre el cual se harán unos breves comentarios.

$79 \mathrm{Al}$ respecto y sin perjuicio de abordar con algún detalle en los apartados $3^{\circ} \mathrm{y} 4^{\circ}$ de este capítulo los debates sobre posmodernidad en historia (especialmente la crítica al concepto "moderno" de tiempo), encontramos un ejemplo en el texto "Sobre el futuro de la historia, el desafío posmodernista y sus consecuencias" (Breisach, 2009, passim). 
Usando la terminología de Northrop Frye en Anatomy of criticism, White clasifica los avatares y el sentido de la búsqueda del héroe según una estructura que diferencia las secuencias relatológicas de aquellas de la tragedia, la comedia y la sátira. Primero habría que hacer una homología entre la idea de "héroe" con las características de un personaje protagónico como el mismo Zaratustra.

Como se dijo en el capítulo dedicado a los fantasmas y la soledad de Nietzsche, Zaratustra puede ser visto como un "doble" de su autor, vale decir, en la génesis del personaje - como fue señalada por Nietzsche mismo- la persona de "Zaratustra" lo asaltó, apareció de súbito, se desdobló del mismo Nietzsche en un pasaje demasiado famoso en las alturas sublimes y despampanantes de Sils Maria en $1883^{80}$.

Desde aquí es posible señalar que los avatares de Zaratustra se encuentran gravitando de una manera específica respecto a los de la vida del mismo Nietzsche, lo cual ha sido señalado por comentaristas como Andrés Sánchez Pascual en la introducción y notas al libro (Nietzsche, 2006).

Aun dudando de la veracidad de ese "asalto" es interesante analizar la manera como Nietzsche explica la condensación mental y poética de su personaje, las ideas expuestas en el apartado correspondiente al Zaratustra en Ecce Homo (Nietzsche, 1995) fortalecen la anterior lectura. Así pues, Zaratustra-Nietzsche inicia una serie de peripecias susceptibles de ser observadas con el lente y desde los presupuestos meta-históricos de Hayden White, con la salvedad de que la naturaleza inclasificable del libro prohíbe asentimientos generales o apodícticos acerca de lo que allí se narra.

Si Así habló Zaratustra no es una obra histórica en el sentido estricto y restringido que la episteme moderna y la historiografía positivista le asignan, es posible valerse de su tramado tropológico para evidenciar el mecanismo textual de su construcción como discurso, justificado esto por las ideas del mismo White al ubicar a Nietzsche como uno de los cuatro grandes filósofos de la historia del siglo XIX.

Si el ochocientos es la época de oro de los estudios históricos, según White, esto se debe al predominio de la retórica y de las consideraciones estilísticas y literarias que guiaban su composición. Vale decir, antes del oscurecimiento de las dimensiones metafóricas del relato por cuenta del positivismo que reinaría en el clima históricofilosófico hasta nuestros días (habría que considerar hasta qué punto inflexiones cruciales como la escuela de los Annales ya en el siglo XX, o la aparición de diversas vertientes de la historia cultural o incluso narrativista han logrado romper con los presupuestos nodales de la pretensión "científica" en la historia ${ }^{81}$ ).

80 Cf. El poema "Rapallo" que Nietzsche escribió a finales de enero de 1883 narra esa "aparición”: “Aquí estaba yo sentado, aguardando, aguardando a nada, más allá del bien y del mal, disfrutando/ Ya de la luz, ya de la sombra, siendo totalmente solo juego,/ Totalmente mar, totalmente mediodía, totalmente tiempo sin meta. Entonces, de repente, ¡amiga!, el que era uno se convirtió en dos / y Zaratustra pasó a mi lado”. De la Introducción de Andrés Sánchez Pascual a la edición de Alianza de Así habló Zaratustra (Nietzsche, 2006, pp. 14-15).

81 Un recuento interesante puede leerse en La revolución historiográfica francesa: La escuela de los Annales (19291989) de Peter Burke (1999). 
En palabras de White, el romance es fundamentalmente

un drama de autoidentificación simbolizado por la trascendencia del héroe del mundo de la experiencia, su victoria sobre éste y su liberación final de ese mundo, el tipo de drama asociado con la leyenda del Santo Grial o con el relato de la resurrección de Cristo en la mitología cristiana. (2001, p. 19)

Si Así habló Zaratustra asume la forma de un romance, lo primero que sería sensato aclarar es el carácter paródico de ésta, la estructura del relato cristiano acerca del nacimiento-muerte y resurrección del héroe se halla seriamente ironizada por Nietzsche.

Podría hacerse una lectura tal ateniéndose al orden en que son presentados los cuatro libros que componen el ciclo de Zaratustra, donde desde las primeras líneas Zaratustra inicia un descenso (untergehen) que luego de muchas peripecias lo conduce a la soledad de su caverna y a los acontecimientos con los hombres superiores en la cuarta parte. Situación que concluye en una suerte de apoteosis final cuando aparece el "signo" y Zaratustra acaba pronunciando sus palabras sobre el mediodía de la humanidad.

Sin embargo, tal supuesta linealidad es contestada por el pasmo y la intuición del eterno retorno. Es decir, si a primera vista son reconocibles huellas de un camino tortuoso o laberíntico pero lineal a fin de cuentas en Zaratustra, tal impresión debe revisarse a la luz penumbrosa de las intuiciones siempre difíciles y escurridizas de la doctrina del eterno retorno. Por ello las afirmaciones de $\mathrm{H}$. White según las cuales el romance "es un drama del triunfo del bien sobre el mal, de la virtud sobre el vicio, de la luz sobre las tinieblas, y de la trascendencia última del hombre sobre el mundo en que fue aprisionado por la caída" (White, 2001, p. 19), sirven como plantilla de contraste, en tono paródico o incluso farsante, respecto de la secuencia narrativa de Así habló Zaratustra.

La idea cosmogónica cristiana de la caída es tematizada explícitamente en el Zaratustra con un signo opuesto al derivado del mito edénico, allí la caída es la marca de una falta moral originaria y prácticamente imborrable. En Zaratustra la caída (untergehen) es una elección soberana de su personaje principal, una necesidad dictada por la sobreabundancia de conocimientos que ha atesorado y decantado en sus diez años de ininterrumpida soledad.

Dicha soledad o soledumbre es un camino, una elección y un campo ontológico de experimentación, no una desgracia o un castigo social, como se anotaba en el segundo capítulo. Se resalta además que la "caída" de Zaratustra implica mezclarse con la plebe y no la pérdida de una aureola primigenia de beatitud y felicidad irrestricta. Además, no se evidencia ninguna autoridad metafísica que ordene tal "caída", abandono del paraíso o algo similar.

La imagen del "salto al abismo" abordada al hablar del primero de cinco momentos escogidos en el camino solitario de Zaratustra, puede reflejar mejor, en cuanto a su carácter dinámico y auto-consciente su primer "descenso" como obertura de la obra. 
Sin embargo, el drama de la redención puede asociarse con la redención temporal de la que se habla en varios apartados, una redención del instinto de venganza del ser humano al no poder desear "hacia atrás".

Todo ocurre como si la condena por un pasado inmodificable pudiera ser sublimada o incluso transmutada en la consciencia de los llamados "hijos de Zaratustra", sus lectores póstumos y predestinados. En el último apartado de este capítulo, además, se verá cómo para algunos autores en el libro desarrolla todo un "drama del alma" que va a transfigurar la identidad del personaje y, por ende, su concepción de tiempo histórico. Para lo cual debe "depurarse" o sublimarse pasando por pruebas tan duras como soportar la visión y posterior enunciación de la monstruosidad que es el eterno retorno de lo idéntico.

Puede afirmarse que la estructura narrativa de Así habló Zaratustra invierte no solo los valores cristianos del libro que parodia explícitamente: la Biblia en la traducción de Marín Lutero. Sino también el sentido del tramado y los avatares del protagonista de acuerdo a las consideraciones meta-históricas de Hayden White. Sin embargo, serán evidentes en la última parte de este capítulo intentos de entender este relato a partir de una transfiguración de la idea de tiempo histórico. Por ahora se harán comentarios acerca en el uso de la metáfora como recurso estilístico y también como herramienta epistemológica.

Caracterizando el uso de la metáfora como una forma de hacer conocido lo desconocido a nivel cognitivo, y considerando innegable el carácter metafórico de toda narración de eventos del pasado -como se sostenía en Metahistoria, F. Ankersmit se va a interesar en superar una visión de la metáfora como "apropiación", es decir, como una forma de reificar algún sujeto trascendental de corte kantiano que busque ordenar el magma caótico de los acontecimientos ${ }^{82}$, en tal sentido se afirma:

La implicación es que la idea y significado históricos son posibles solo gracias al uso de los tropos y que, por tanto, es precisamente la tropología la que puede revelarnos cómo la disciplina de la historia realmente forma parte del esfuerzo occidental y fáustico de conquistar de manera cognoscitiva el mundo físico e histórico que habitamos. En una palabra, la tropología es a la historia lo que la lógica y el método científico son a las ciencias. (Ankersmit, 2004, p. 27)

Es por ello que tal "conquista" se denuncia como parte de un dispositivo de dominación propiamente "moderno" que debe ser desmontado, reconociendo el carácter metafórico del relato histórico pero buscando ir más allá de él. Se trata de reconocer un perspectivismo connatural a la forma como contamos el pasado, haciendo uso de recursos que deben explicitarse como artificios, como exigía también Nietzsche, y no tomarse como universales categóricos:

82 "Esta teoría de la experiencia histórica debe reconocer la autenticidad de la experiencia histórica como un símbolo de su disposición a abandonar las pretensiones del yo trascendental de hacer conocido el mundo (histórico) en la manera que siempre ha sido propia del yo trascendental" (Ankersmit, 2004, p. 67). 
La metáfora es probablemente el instrumento lingüístico más poderoso que tenemos a nuestra disposición para transformar la realidad en un mundo adaptable a las intenciones y propósitos humanos. La metáfora "antropomorfiza" la realidad social y en ocasiones incluso la física y, al hacerlo, nos posibilita apropiarnos y convertir en algo conocido esa realidad. (Ankersmit, 2004, p. 34)

Así las cosas y siempre en resonancia con los planteamientos de Hayden White en obras como Metahistoria y más recientemente en El contenido de la forma (White, 1992), la metáfora no es solo un recurso expresivo secundario, sino que se sitúa en el corazón mismo de nuestra forma de conocer específicamente moderna, la metáfora es un artilugio para darle consistencia a nuestra visión del mundo y no solo una figura para adornar el relato de los hechos del pasado.

Los asuntos de "forma" expresiva o incluso estilística tienen una extraordinaria relevancia a nivel del contenido mismo de lo que se narra, e incluso más allá, a nivel del "campo de prefiguración" del espacio gnoseológico en el que se mueve el historiador. Es por ello que para estas posturas la concepción nietzscheana del mundo y la verdad como algo elaborado lingüísticamente es un antecedente clave.

Antes de pasar a considerar aspectos específicos de esta teoría narrativista de la historia y relacionarla con algunas posturas nietzscheanas, se revisará lo que dice Keith Jenkins, otro teórico de la historia abanderado de la llamada historia posmoderna: "Así, la historia de la Tradición Occidental, viviendo a la sombra de Platón, ha sido abrumadoramente la historia de diversas articulaciones de semejante fantasía estabilizadora, a guisa de verdades eternas expresadas ahora en las ya familiares mayúsculas" (Jenkins, 2006, pp. 52-53).

El autor se está refiriendo a la Verdad con mayúscula, la Objetividad con mayúscula y así sucesivamente. Aquí también queda clara la necesidad de desmitificar tales "fantasías estabilizadoras" como los "errores irrefutables" de los que habló Nietzsche y que aunque son necesarias para dar piso epistemológico a las valoraciones que determinan como cierta una particular imagen del mundo, no por ello deben tomarse como intrínsecamente ciertas.

Una de las primeras tesis de la filosofía narrativista, según Ankersmit, sostiene: "1.1 Los términos narración histórica e interpretación son mejores pistas para comprender la historiografía que los términos descripción y explicación” (2004, p. 71). "Explicar" nos situaría dentro del marco de referencia del pensamiento científico, y lo que quiere proponerse es precisamente un modelo interpretativo de los acontecimientos del pasado, el uso de un vocabulario más adecuado a este fin es entonces el primer paso. Luego, se propone el horizonte de la narrativa histórica en estos términos:

Los historistas intentaron descubrir la esencia, o como ellos la llamaron, la historische Idee, que supusieron presente en los propios fenómenos históricos. Por el contrario, la narrativa reconoció que una interpretación histórica proyecta una 
estructura sobre el pasado y no la descubre como si esta estructura existiera en el pasado en sí. (Ankersmit, 2004, p. 76)

Esa "proyección" estructural es una forma de configurar la voluntad de poder en términos de Nietzsche, de acuerdo a su famoso postulado "no hay hechos, solo interpretaciones", la narrativa histórica es una manera de realizar un juicio de valor o interpretación sobre el pasado. Tal perspectiva no tiene nada que ver con la "naturaleza de las cosas" o con algún sentido inherente a ellas, las narrativas son cuadrículas para el posicionamiento de una forma de percibir el mundo, con lo que la idea de "descubrir" en ese pasado histórico regularidades o significados propios es absurdo, lo que ocurre es que tal significado depende de los recursos epistemológicos que en cada época determinan las posibilidades narrativas del historiador, por lo que va a ser de mucha importancia la proliferación de hipótesis interpretativas sobre el pasado y no su estabilización en una sola forma de considerarlo:

En última instancia, el debate historiográfico no pretende generar consensos, sino la proliferación de tesis interpretativas. El propósito de la historiografía no es la transformación de las cosas narrativas en cosas reales (o en sus conceptos tipo). Al contrario, intenta producir la disolución de lo que parece conocido e indubitable. Su objetivo no es la reducción de lo desconocido a lo conocido, sino el extrañamiento de lo que parece conocido. (Ankersmit, 2004, p. 87)

En este numeral de las tesis sobre la filosofía narrativista en historia se sintetizan muchas de sus pretensiones a nivel epistemológico. Como con Nietzsche, lo valioso aquí no es la consolidación excluyente de un relato de lo acontecido, como si otras aproximaciones fueran menos válidas o adolecieran de "subjetividad" o "inexactitud" respecto de lo "realmente ocurrido", sino que el papel de la historia es desestabilizar y poner en perspectiva cualquier aproximación al pasado.

Ese era igualmente el rol de esa particular conjunción de historia "monumental", "anticuaria" y "crítica" que fue caracterizada en la segunda Intempestiva (Nietzsche, 2000, pp. 147-160). La historiografía no convalida ningún metarrelato tenido por verdadero, por gnoseológicamente verdadero, sino que muy en resonancia con la terea de la genealogía, la idea es "desnudar el mecanismo" que configura las visiones estructuradas del pasado: "abrir la caja negra”, des-construir los discursos autorizados, vertiendo un disolvente crítico sobre ellos y más bien exhibiendo las condiciones a partir de las cuales se hizo posible una cierta forma de narrar esos eventos.

Como una suerte de fármakon, y según hemos afirmado a lo largo de este libro, la narrativa histórica construye y mantiene una visión del mundo dada, la sostiene, la teje de acuerdo a condiciones precisas, a estilos de metaforización propios de cada época. Pero simultáneamente tal narrativa critica esas visiones del mundo, al historizarlas las relativiza, las hace contingentes, muestra su dependencia de relaciones de poder y dispositivos de saber que cambian de momento a momento, incluso para proponer con Jenkins "deshacernos de la carga del pasado": 
Quizá no haya ninguna razón para que no podamos reunir la fuerza, como dijo Nietzsche, para deshacernos de la carga del pasado y la ética pasada y construir futuras mediaciones de emancipación radical a partir de los imaginarios actuales y, más particularmente en nuestro propio tiempo y lugar, de los imaginarios posmodernos. ${ }^{83}$ (Jenkins, 2006, p. 17)

En resonancia con lo anterior se lee en el libro "Historia y Tropología": "los últimos capítulos exploran las posibilidades de tal forma de escrito histórico y conciencia histórica no kantianos y no metafóricos" (Ankersmit, 2004, p. 45). Se dice no kantianos al desautorizar la referencia a un sujeto trascendental que no fuera él mismo un resultado o efecto de mecanismos de creación de la subjetividad históricos. Y "no metafóricos" no porque se abandonara o cuestionara el carácter indesligablemente metafórico de nuestra forma de entender el pasado, como ha sido dicho, sino para dejar de considerar la metáfora como una forma logo-céntrica de "apropiación" de lo supuestamente desconocido en maquetas epistemológicas manejables.

Se reserva para el tercer punto de este capítulo un examen más detallado, a partir de las formulaciones de Jenkins, de la idea de "abandonar la historia", o sea las formas específicamente modernas de hacer historia, como siempre quiso Nietzsche de acuerdo a su filosofía transgresora y trans-valoradora.

\subsection{VALORACIÓN HISTORIOGRÁFICA DEL PENSAMIENTO DE NIETZSCHE}

Pasando a la relación entre la obra de Nietzsche y la historia y sus metodologías, parece importante citar a Thomas Brobjer, quien sostiene "Nietzsche is generally regarded as a severe and hostile critic of historical studies, and it is possible that the expression 'historical sickness' (historische Krankheit) was made current through him" (Brobjer, 2004, p. 301).

Sin desestimar la valiosa metáfora de la historia como "enfermedad", lo que quiere hacerse es mostrar la valoración de Nietzsche sobre los métodos históricos más allá del estereotipo de simple "destructor" a martillazos de cualquier clase de estudio histórico. Vamos a ver que reducir a Nietzsche a un papel de negador tout court de la historia es empobrecerlo y simplificar la riqueza de sus consideraciones sobre el pasado, especialmente en su perspectiva más crítica y des idealizadora:

I have argued that On the Uses and Disadvantages of History for Life is not representative of Nietzsche's views of history generally, and that historical studies and methods were much more important to him than has been recognized [...] although he continued to regard a too strongly emphasized sense of history as dangerous, he also regarded

83 Sobre el término posmoderno y sus implicaciones remitimos al trabajo "Deconstructing history", en el que se hace una aproximación a este como transmutación de los valores de la modernidad, no como una época que la sucede o que se tornará hegemónica (Munslow, 1997, p. 2). 
historical studies and methods as necessary for culture. (Brobjer, 2004, p. 321)

Vale decir, no puede partirse exclusivamente del disvalor de la historia como inflación de erudición vacua y farragosa por parte de Nietzsche. Se hace una distinción muy importante, la historia como meta en sí misma, despojada de consideración sobre su utilidad o perniciosidad para un fortalecimiento de las condiciones vitales de una cultura, de la historia como crítica a los modos establecidos de darle sentido a los hechos del pasado.

En esta última óptica, la historia sí fortalece la vida, es decir, los estudios históricos desmitifican la universalidad de las formas establecidas de ver el mundo, ponen en perspectiva los modos de otorgarle sentido a los acontecimientos, especialmente los acontecimientos ya acontecidos. Así, la historia es una herramienta vital en el intento trans-valorador del filósofo: "what Nietzsche objected to primarily in regard to history was not the new methods introduced in the early part of the nineteenth century, but that history was placed above philosophy that history and historical scholarship were seen as the goal" (Brobjer, 2007, p. 177).

Este mismo autor sitúa el giro post-shopenhaueriano de Nietzsche después de la publicación del Nacimiento de la tragedia y las cuatro Consideraciones intempestivas justamente en su contacto más íntimo con la historiografía del siglo XIX. Lo que daría origen al periodo que inicia con "Humano, demasiado Humano" sería esa familiarización de Nietzsche con la obra de Ranke, por ejemplo, con lo que queda refutada la idea de un desprecio de Nietzsche por la Historia y sus metodologías a todo lo largo de su obra, o la imagen de su doctrina del "eterno retorno" como algo ahistórico que daría al traste con cualquier tentativa de estudiar históricamente fenómenos como la voluntad de poder, las tablas morales y los criterios para construir imágenes plausibles del pasado.

During his third period, he begins increasingly to emphasize the importance of values (cf. his revaluation project)- a field in which historians have been remarkably unsuccessful, and often strongly anachronistic- which makes him move in the direction of using history for the purpose of criticizing values and for showing that their origin and earlier use mostly were very different from what one would naturally think. (Brobjer, 2007, p. 178)

El "tercer periodo" de Nietzsche, del cual es representativa la "Genealogía de la Moral" se sirve de las pesquisas históricas de una forma privilegiada, con lo que es insostenible su supuesto desprecio o rechazo por cualquier clase de estudio histórico. Lo que se aprecia en esa obra es justamente una relativización de los horizontes morales al situarlos en perspectiva histórica, al desentrañar las condiciones históricas de su surgimiento.

No hay que perder de vista sin embargo, que aún desde la Segunda Intempestiva (Nietzsche, 2000, pp. 35-48), Nietzsche clarifica que la nocividad de los estudios históricos no está en ellos mismos, sino en su uso en términos de un empobrecimiento 
de la riqueza interpretativa propia de la vida. Allí donde el olvido es una condición indispensable para la reconfiguración incesante del devenir, y no un defecto a corregir desde la proliferación meticulosa de estudios carentes de sustancia crítica:

Nietzsche's critique of history and historical thinking has been widely misunderstood (to a large degree because of the somewhat misleading nature of Vom Nutzen und Nachtheil der Historie für das Leben) as an overall critique of historical thinking, including historical method. This is not correct (Brobjer, 2007, p. 179).

Se analizará ahora la compilación editada en 2008 Nietzsche on Time and History, correspondiente a las colaboraciones presentadas en Cambridge durante la celebración de la $15^{\circ}$ conferencia Internacional de la Friedrich Nietzsche Society en septiembre de 2005. El editor e introductor del volumen Manuel Dries, scholarship de la Universidad de Cambridge, agrupa esas conferencias en lo que él llama la critica de Nietzsche al "estaticismo" [Nietzsche's Critique of Staticism], por eso afirma en la introducción al texto:

His [Nietzsche] focus on history and his rehabilitation of time is first and foremost concerned -and so are the fourteen essays in Nietzsche on Time and History- with the proof that staticism about persons, objects, entities such as nations, the law, truth, or the linear future of time and history itself is false. And yet, most contributions reach a point where a different conception is called for. (Dries, 2008, p. 11)

De entrada es posible concretar esta noción "estaticista" con las pretensiones científicas de la narrativa histórica, las cuales fueron trabajadas iniciando este apartado. Es decir, también con un temor a abordar el devenir de los acontecimientos para fijarlos en moldes de los cuales se olvida su carácter fabricado y acomodaticio. Dando como resultado la incapacidad de enfrentar la mutación de los eventos y encasillarlos en esquemas que en sí son solo elaboraciones de la voluntad de poder.

Plantillas clasificatorias que luego son reificados, entre otras, por instancias y hábitos lingüísticos, convirtiéndolos en horizontes fijos y justamente "estáticos" que ahogan y petrifican el devenir mismo de manera empobrecedora o agobiante. Así se observa en concreto a qué se refiere Dries con "estaticismo": "by "staticism" I mean roughly speaking and in general, the view that the world is a collection of enduring, re-identificable objects that change only very gradually and according to determinate laws" (Dries, 2008, p. 9).

Esta visión de las formas de "estabilización" de las cosas concierne especialmente a este trabajo en cuanto a la noción de "tiempo histórico" se refiere. Según Dries allí está el meollo del aporte de Nietzsche sobre el tiempo y la historia, en el desafío a la "maqueta" tomada por realidad, pero que no corresponde sino a "estatizaciones" o cristalizaciones de un devenir infinitamente voluble y plástico. Lo que acontece es la fabricación narrativa de un enfoque sobre lo ya acontecido. El peligro, entonces, es caer presas de esta construcción como algo intrínsecamente sólido, válido a priori, considerándolo epistemológicamente inamovible, ese es el error que no se cansó de señalar Nietzsche. 
En el texto de Andrea Orsucci "Nietzsche's cultural Criticism and his Historical Methodology", incluido en la primera parte de Nietzsche on Time and History, se abordan cuestiones que ya apuntadas al leer los artículos de Thomas Brobjer. Sobre él dice en la introducción Dries:

It is the historical phenomena themselves that, according to Orsucci, Nietzsche's method reveal as consisting of a complex simultaneity of temporal and historical layers, consistently concerned to identify and theorize the coexistence and mixing of very different traditions, cultures, and ways of thinking in any particular historical phenomenon" (Dries, 2008, p. 12).

Desentrañar la complejidad configurante de capas de realidad adosadas a los eventos del pasado sería el trabajo de la metodología histórica. Revisar el esquema compositivo de elementos tan heterogéneos como las formas de pensamiento, las tradiciones, la idea de tiempo de que se disponga etc., que sumados fabrican los fenómenos históricos [historical phenomenon], es esta una perspectiva sumamente interesante porque no solo refuerza la idea de la artificialidad del relato histórico, sino que brinda pistas específicas en el trabajo historiográfico.

Se trata así de desmontar los modos de su elaboración, discernir capas y niveles cognitivos implicados en la construcción de su narrativa. La imagen de una simultaneidad de niveles temporales [the complex simultaneity of temporal and historical layers] reta con relación a esos "dispositivos" como madejas de signos heterogéneos que hay que des-construir. Sobre todo cuando una de esas capas como un "túnel de realidad" es la idea de tiempo atrayendo de manera irresistible la forma de ordenar los datos por parte del historiador.

Por su parte, John Richardson en "Nietzsche's Problem of the Past" aborda los posibles desarrollos de una postura "genealógica" en los estudios históricos, desmitificando los valores como interpretaciones que inconscientemente hacen los individuos y que los atan a formas valorativas exógenas. Desde allí se propone una revisión de la voluntad "proto- intencional" que mantiene a los sujetos atados a la pesadez de horizontes morales establecidos: "Nietzsche's genealogical method is therefore a technique to become aware of the proto- intentional "wills", to expose the social formation of values, and in a retrospective stance to bring into view "the forces that really aimed the rules and values to wich I commit myself” (Dries, 2008, p. 107).

El objetivo será dejar de honrar pactos en los que no se ha participado, o sea incumplir compromisos éticos que son impuestos y luego tenidos por obvios en las formas oficiales de asumir el pasado. Tal sería el potencial crítico de una actitud genealógica asumida sin reservas: "Genealogy enables us to judge those designed-in purposes of our ways of thinking and acting - and decide whether we favour those purposes"(Dries, 2008, p. 108).

El ensayo "Nietzsche's Musical conceptions of Time" de Jonathan R. Cohen se sitúa aún más dentro del núcleo problemático que concierne al análisis de la 
temporalidad como constructo. De manera privilegiada se van a conectar los aportes de la crítica de Nietzsche a Wagner (Nietzsche, 2002) con una consideración sobre las desventajas fisiológicas que atmo-terroristamente puede tener un cierto tipo de melodía y de musicalidad cuando se vuelve dominante, como ocurrió con la música de Richard Wagner: "Cohen concludes that Nietzsche's emphasis on time as it is experienced correspond to Nietzsche's insistence that each subject has its own internal rhythm and temporality, derived from, among other things "our internal physiological rhythms: breathing rate, heart rate, metabolism" (Dries, 2008, p. 299, subrayado añadido).

Como en la primera referencia a Frank Ankersmit (2004) se aprecia una desconstrucción de la idea de tiempo como marco extra-subjetivo y único, pero aquí además se brindan pistas clave en la consideración sobre las posibles temporalidades individuales o particulares de cada quien:

The criterion for evaluating music then becomes its effect on us: "it can help structure our internal rate of time - either directly or by providing a contrasting rhythm to serve as benefical tonic- or it can harm it. And with no time-in-itself to fall back on, such undermining can be utterly destructive. It requires great strength to resist it and maintain one's own tempo". (Dries, 2008, p. 300)

Retornando a las consideraciones llamadas "atmo-sismo-gráficas" en el anterior capítulo, se ve $y$ se oye aquí que la música es parte fundante de esa modelización ambiental que históricamente sitúa los moldes de sensibilidad de los individuos, violentándolos en muchos casos, como fue ensordecedoramente evidente para Nietzsche respecto a Wagner y sus mega-orquestaciones retumbantes.

El tiempo es la sumatoria de ciclos biológicos presentes en el cuerpo mismo del sujeto, no una medida abstracta con carácter universal o incluso arquetípico. Sin auxilio de alguna noción de "tiempo-en-sí-mismo" cada uno tiene la tarea de ritmar cadencias temporales propias y artísticamente configuradas: "the possible existence of time-in-itself. Though undeniable, is irrelevant to us. But this is as much as to say that there is no time-in-itself for us - the only time that matters is time as we experience it" (Dries, 2008, p. 303).

En tal empeño se cifraría la conclusion, de la mano de Jenkins, de este capítulo; pero antes de ello nos parece pertinente interpolar en este punto las ideas de George Grant en su obra Time as History, donde el papel de Nietzsche para una crítica de la idea moderna de temporalidad es bien destacado: "In my opinion the thinkers who thought the crisis of western civilization most intensively and most comprehensively was Nietzsche. And often his thought about that crisis was centered about the notion of time and of history" (Grant, 1995, p. 6).

Hablar de crisis de la civilización occidental es ya un lugar común, pero lo relevante es el modo como se diagnostica esta crisis según la idea de "temporalidad" y en especial según los aportes de Nietzsche en esas materias: 
In his work [Nietzsche], the themes that must be thought in thinking time as history are raised to beautiful explicitness: the mastery of human and non-human nature in experimental science and technique, the primacy of the will, man as the creator of his own values, the finality of becoming, the assertion that potentiality is higher than actuality, that motion is nobler than rest, that dynamism rather than peace is the high. (Grant, 1995, p. 8)

El eje de esta crítica es la forma como la modernidad en Occidente asoció a una temporalidad irreversible y lineal el concepto de historia, deificando los desarrollos tecnológicos dimanantes de una epistemología científica servil a sus postulados. Desde estas ideas el autor se sitúa los aportes de Nietzsche por encima de muchos otros, superioridad que depende de la perspectiva valorativa que se tome, sobre todo si es en la idea de "tiempo" y sus concreciones más expeditas en el campo de la narrativa histórica, que se juega la naturaleza de tales "metarrelatos" modernos:

Nietzsche thinks what it is to be a modern man more comprehensively, more deeply, than any other thinker, including Marx, including Freud, including the existencialist, including the positivists. Nietzsche excelled all these because, in recognizing and preaching the historical sense, he had declared that all frameworks, all perspectives, were human creations. (Grant, 1995, p. XV)

Estaes unavaloración muyrelevante dela obra de Nietzschecomodesenmascarador de imposturas [frameworks, perspectives] justamente al historizarlas, al mostrar sus condiciones de aparecimiento y el devenir de sus incesantes transformaciones, como contingentes creaciones humanas [human creations] y no como regularidades intrínsecamente ciertas. La preferencia por el sentido histórico sería entonces una constante a lo largo de su obra, ya que gracias a él podía desmitificar incluso la noción de temporalidad más allá de su reificación en la cotidianidad del mundo dado por descontado.

\subsection{TRANSVALORACIÓN DE LA TEMPORALIDAD, DECONSTRUCCIÓN, NARRATIVA HISTÓRICA Y POSMODERNIDAD}

En esta tercera parte se iniciará reseñando ideas del extraordinario libro de Robin Small, publicado en 2010, “Time and becoming in Nietzsche's thought", las cuales servirán para enlazar las intuiciones dispersas en los dos primeros apartados y dirigirlas hacia el concepto de tiempo histórico. Resulta indispensable comenzar situando el interés de Small por la preferencia literaria y metafórica de Nietzsche en sus escritos:

It is true that Nietzsche is unusual among philosophers in his reliance on literary modes of presentation. Yet we need to bear in mind his insistence on the 
metaphorical character of our ordinary concepts, which undermines the whole distinction between the metaphorical and literal [...], the hidden complexities of the corresponding, suggesting that each may usefully throw light on the other. (Small, 2010, pp. IX-X)

La temporalidad como metáfora en sí misma, tal idea no solo puede ser una de las conclusiones de esta cita o de este acápite, sino del libro TEMPUS EX MACHINA en su conjunto. El tiempo como shifter o modelizador privilegiado tanto para el historiador interesado en dar coherencia narrativa a su versión de los acontecimientos del pasado, como para todo sujeto obligado a estructurar también una narrativa para su vida, de acuerdo a criterios de metaforización contingentes, que mutan según las épocas, de acuerdo a sensibilidades que entran siempre en devenir.

La relativización de la distinción entre lo metafórico y lo real, en este sentido, opera como un catalizador clave. Lejos de constituir una concesión a la "cualquierización" empobrecedora de los recursos interpretativos del historiador, o un hundimiento en el nihilismo radical, tal relativización le permite ser consciente de que incluso el nivel menos metafórico, el más literal que pueda imaginarse es ya una transcripción de estímulos a un lenguaje constitutivamente figurado.

Es decir, las fórmulas y algoritmos matemáticos menos metafóricos posibles ya son metáforas de un devenir inenarrable, y mucho más respecto a las convenciones del historiador. En su calidad de género narrativo, la historia traduce signos y encadenamiento de signos, acelerando o desacelerando su circulación de manera indefectiblemente metafórica.

La gran relevancia de Nietzsche en estos aspectos, como quedó dicho en el anterior apartado, está en la crítica histórica que se hace a esos horizontes narrativos. Al usar intensivamente tropos y otras modalizaciones estilísticas - especialmente en Así habló Zaratustra - no se está más lejos de lo real, sino en su corazón ambivalente y retóricamente ambiguo. El llamado de atención de Robin Small se sitúa de lleno en este orden de ideas:

His [Nietzsche] critique of moral concepts such as responsibility, guilt and punishment involves tracing their source to the problematic human relation to past and future. In consequence, the mission of overcoming the prejudices of morality that he assigns to himself depends on the possibility of uncovering new forms of temporality. (Small, 2010, p. 2)

Si el tiempo es una interpretación de la facticidad plural y mutágena del devenir, entonces es posible refigurar tal metáfora, queda claro que "for Nietzsche becoming is a fact but time is an interpretation" (Small, 2010, p. 2). Lo que hace cada ser vivo, entonces, es indexar lingüísticamente la complejidad excesiva del devenir como tal, gramaticalizando en convenciones temporales algo que las desborda siempre. Como decía Manuel Dries: "estatizando" o dando un valor de verdad a sus fabricaciones, a la condensación histórica de sus impresiones. 
De allí que se sostenga "every perspective on reality arises out of a certain form of life and expresses the interpretations and, in particular, the valuations that are its conditions of existence" (Small, 2010, p. 2), emparentando fisiología y axiología se considera que cada organismo crea horizontes temporales de acuerdo a ritmos y ciclos experimentados como vitales para su sobrevivencia.

En resonancia con las intuiciones de Jonathan Cohen en "Nietzsche's Musical conception of Time" sumariadas más arriba, la imagen que aquí se presenta es la de una inagotable cantidad de posibilidades de temporalización, ligadas también a la percepción particular de la duración y de la sucesión o periodización de los estímulos sensibles. Distinciones capitales en el trabajo historiográfico resultan ser esquemas operativos modulables: "we separate rest and motion, although in reality there are only variations in the tempo of becoming" (Small, 2010, p. 5).

Tales variaciones en el tempo, son mutaciones intensivas antes que casillas fijas, flujos de multiplicidades inexhaustibles y no marcas cronológicas con valor propio. Por ello la metáfora es una forma de dar fluidez a esas interpretaciones. Jesús Conil al respecto sostiene: "Nietzsche vendría a recuperar la actividad de la transformación de metáforas en el proceso de instauración de signos, en el juego de significaciones sin sentido propio, como parodia de la metafísica que vivía de la aparente identidad del significado" (Conil, 1988, p. 144).

Ese juego de las significaciones es equiparable al devenir incesante de las ideas de tiempo, que no solo se alteran según los grandes periodos históricos, sino que lo hacen muchas veces en la vida de un individuo. Incluso a cada momento se vive la incompatibilidad de ciertos marcos de ordenación causal de los acontecimientos y estos mismos en su carácter súbito, paradójico e impredecible. Y mucho más en el caso del historiador, cuyo material de trabajo son las huellas de un pasado arremolinado en esos flujos pre- temporales y pre-cronológicos del Devenir y la voluntad de poder.

Cambiar el valor del tiempo como se halla históricamente expresado en los relatos de los historiadores es, pues, la tarea central: "para superar la metafísica que ha engendrado el nihilismo hay que redimir al hombre de la venganza, lo cual solo es posible cambiando el sentido del tiempo y el valor del devenir" (Conil, 1988, p. 153, subrayado añadido). Este autor español conecta así el nihilismo como Zeitgeist - y al que fue Nietzsche tan sensible - con una idea de "redención" radicalmente distinta de los discursos transmundanos del cristianismo.

El cambio de valor o transmutación se asocia a la des-construcción del espíritu de la venganza instaurado y naturalizado en la idea moderna de tiempo, de conexión causal a ultranza, de fijación de antecedentes y responsabilidades en el flujo inocente de los eventos. Con mayor claridad se lee en esta cita:

El ser se disuelve en el tiempo, que se convierte en la perspectiva plural del ser, que ya no puede quedar fijado en nada. [...] Nietzsche se adentra en el misterio del tiempo, proponiendo una nueva concepción del tiempo y del devenir [...] 
el descubrimiento trágico del tiempo al margen de cualquier seguridad. AMOR FATI, Amor al destino en el devenir. (Conil, 1988, p. 157)

Esta "nueva concepción de tiempo" no es un ídolo de reemplazo o alguna nueva trascendentalización de ideas cronológicas, es constatar el vacío fundante y no esencial del devenir. Sobre esto, las frases de Foucault que servían de epígrafe al capítulo resuenan con particular contundencia: "creemos que nuestro presente se apoya en intenciones profundas, necesidades estables; pedimos a los historiadores que nos convenzan de ello. Pero el verdadero sentido histórico reconoce que vivimos, sin jalones ni coordenadas originarias, en miríadas de acontecimientos perdidos" (Foucault, 2008, pp. 50-51).

En su lectura de Nietzsche, Foucault entiende que la historiografía no puede complacer por más tiempo las necesidades de los meta-relatos modernos sobre la historia. En consonancia con la filosofía narrativista de Ankersmit, citada abriendo este capítulo, la historiografía dispersa las estatizaciones valorativas acerca del pasado, con lo que "se trata de hacer de la historia un uso que la libere para siempre del modelo, a la vez metafísico y antropológico, de la memoria. Se trata de hacer de la historia una contra- memoria, y de desplegar en ella, por consiguiente, una forma totalmente distinta de tiempo" ${ }^{84}$ (Foucault, 1979, p. 25).

De forma provocadora y en resonancia con lo anterior, reclamaba K. Jenkins que "ahora podría ser posible y deseable pensar en visiones no históricas del tiempo y en moralidades relativistas, aporéticas" (Jenkins, 2006, p. 58, subrayado añadido). Como colofón de lo anterior escuchamos de nuevo sus palabras ${ }^{85}$, quien en “拜or qué la historia?", al pasar revista a los aportes de personajes como Jacques Derrida, Jean Baudrillard, o Jean François Lyotard entre otros, plantea la posibilidad de emanciparnos de la moderna y logocéntrica noción de tiempo histórico:

La historia ha sido tan fuerte en la formación de nuestra cultura, tan central fue su lugar en el "experimento de la modernidad" burgués y proletario, que casi parecería que la historia es un fenómeno natural: siempre hay un pasado, y por tanto nada más natural que existan historias de él. Pero, por supuesto, la historia no es en absoluto un fenómeno natural ni tiene nada de eterno. En una cultura, nada cultural es, por definición, "natural"; por consiguiente, ningún discurso es sino un fenómeno contingente. Por tanto, no hay necesidad de pensar que el tiempo necesita ser expresado históricamente. (Jenkins, 2006, p. 27)

Apoyando lo anterior, en "The deconstruction of time", primero publicado en 1989 con una reimpresión en 2001, David Wood se refiere a la idea de "tiempo" como

84 En el siguiente numeral vamos asociar esta "contra-memoria" al Rizoma en la filosofía de Deleuze y Guattari, a los devenires y las líneas de desterritorialización, así como a la temporalidad aiónica como diversa al modo de captura temporal de Cronos.

85 "[Ya] que las condiciones óptimas para la creación y el sostén de la historia están ahora detrás de nosotros, y [ya] que ahora debemos olvidar tales configuraciones y abrazar un posmodernismo no historizante" (Jenkins, 2006, p. 25). 
concepto clave en el proceso de asignación de orden a los acontecimientos: "We need them [concepts] to order our world, but if we treat them as more tan useful tools, we fall victim to illusions of our own manufacture" (Wood, 2001, p. xvii). Esa ilusión expresada en protocolos de escritura propios del quehacer historiográfico eran los que Keith Jenkins relativizaba, es decir, la compulsión a organizar los eventos en cadenas causales y líneas de inteligibilidad derivadas de las grandes narrativas históricas.

El asunto, en este espacio de tiempo calificado de "post-moderno", es visibilizar la naturaleza construida de tales fantasmagorías, sobre las cuales el autor del Zaratustra echaría una luz peculiar: "broadly speaking, Nietzsche's account is treated as a reflective intensification of our understanding of the "present", one that succesfully subverts our everyday "recuperative" understanding" (Wood, 2001, p. 12).

Las anteriores frases son tomadas del primer capítulo del texto de Wood acabado de referenciar y que se titula precisamente "Nietzsche's transvaluation of time". Lo anterior indica que la famosa transvaloración valorativa implica necesariamente una correlativa transvaloración temporal, indicada como una des-construcción de la "metafísica de la presencia" y su obsesión por el presente, parte también de una lógica "recuperativa" que ubica los eventos en líneas de temporalización disponibles para un tipo de memoria específica. Ese tipo de memoria "recuperativa" o incluso "arborescente o molar" puede ser descrita en estos términos:

los neurólogos, los psicofisiólogos, distinguen una memoria larga y una memoria corta (del orden de un minuto). Ahora bien, la diferencia entre ellas no solo es cualitativa: la memoria corta es del tipo rizoma, diagrama, mientras que la larga es arborescente y centralizada (huella, engramma, calco o foto). La memoria corta no está en modo alguno sometida a una ley de contigüidad o de inmediatez a su objeto, puede ser a distancia, manifestarse o volver a manifestarse tiempo después, pero siempre en condiciones de discontinuidad, de ruptura y de multiplicidad. (Deleuze \& Guattari, 1997, p. 21)

En tal sentido la memoria corta y el tipo discontinuo de escritura histórica que apareja, no son solo "innovaciones" de una crítica postmoderna a los modos tradicionales de asumir el relato del pasado, sino que se trata de un modo diferente de agrupar las huellas mnémicas. El llamado de Jenkins y otros a renovar el arsenal de recursos interpretativos y estilísticos, así como a abandonar, o mejor "transmutar" viejos moldes trascendentales -incluida la idea de "tiempo"- 86 no corresponde solo al capricho de una moda intelectual, sino a la consideración de dimensiones de la temporalidad y a modos de memorización invisibilizados en la epistemología moderna de tipo "arborescente".

86 Particularmente relevante para nosotros resulta el libro de Elisabeth Deeds Ermart (Ermarth, 1992) que aborda de manera directa la crisis del tiempo moderno "representativo", inspirada por temporalidades propias de la narrativa literaria, especialmente el tiempo "rítmico" de obras como Rayuela [Hopscotch] de Julio Cortázar, Keith Jenkins dedica un capítulo de ¿Por qué la historia? a su obra (Jenkins, 2006, pp. 271-304). 
Es más, las dos memorias no se distinguen como dos modos temporales de aprehender una misma cosa, no captan lo mismo, el mismo recuerdo, ni tampoco la misma idea. Esplendor de una idea corta (concisa): se escribe con la memoria corta, así pues, con ideas cortas, incluso si se lee y relee con la memoria larga de los amplios conceptos. La memoria corta incluye el olvido como proceso; no se confunde con el instante, sino con el rizoma colectivo, temporal y nervioso. La memoria larga (familia, raza, sociedad o civilización) calca y traduce, pero lo que traduce continúa actuando en ella a distancia, a contratiempo, "intempestivamente", no instantáneamente. (Deleuze-Guattari, 1997, p. 21)

Tal "cortedad" de la memoria es asociada al carácter fragmentario y discontinuo del acontecimiento mismo. Como un verdadero vector de desterritorialización, ese modo de la memoria desconfigura la fijeza de estratos temporales asegurados por el trabajo de los historiadores. Se recuerda aquí cómo Michel Foucault había emprendido su proyecto arqueológico con la intención de deshacer continuidades dadas por obvias y compulsiones hermenéuticas tan arraigadas como la idea de "obra" o de "autor" (Foucault, 1997), centrando su análisis en el "enunciado" como acontecimiento, sus posibilidades de irrupción y trastocamiento de continuidades dadas por obvias.

Con ello se pretenden revisar los procedimientos que han permitido la toma de consistencia de grandes ideas acerca del pasado, periodos históricos e incluso el sentido dado a esos eventos por parte del historiador. He allí la insistencia de esa memoria corta tipo rizoma actuando a contrapelo o intempestivamente. La propuesta será pensar un tipo de escritura histórica en resonancia con ese modo descentrado e híbrido de hilvanar los acontecimientos.

Deconstruir indicará no solo un gesto negativo, sino un modo de investigación, una sensibilidad atenta a desentrañar las estrategias de construcción de grandes referentes: "And one of the distinctive virtues of deconstruction, certainly as Derrida practices it, has been his reflection on the singularity of philosophical events, poking at conventional framing assumptions until they squeak (or tremble) a little" (Wood, 2001, p. ix).

Considerando de manera particular el concepto moderno de tiempo, y adentrándose ya en los planteamientos de Nietzsche sobre el tópico, el mismo autor sostiene: "The traditional betrayal of time would consist of subjugating the values associated with Becoming to those of Being" (Wood, 2001, p. 13). Con lo que esa "traición" [betrayal] queda caracterizada en la inmovilización del devenir [Becoming] al construir secuencias temporales que acaban privilegiando valores del "Ser" [Being]; por ello es tan importante una consideración no metafísica del eterno retorno: "I shall begin by arguing that the various ways in which eternal recurrence is formulated reflect the different modes (levels, dimensions) at which time needs to be transvaluated or 'deconstructed'” (Wood, 2001, p. 14).

Esa tarea des-constructiva centrará su atención en la aparente neutralidad e independencia de la dimensión temporal de la historia, ya que lo primero que debe 
ponerse en cuestión es la idea misma de temporalidad como algo dado, una constante universal o un aspecto no construido o no deudor de contextos históricos específicos: "timetables, time and motion measurement, schedules, clocks, system coordination all work on the assumption that time can be deployed as an independent dimension" (Wood, 2001, p. xii).

Desde aquí es posible una consideración del eterno retorno nietzscheano desembarazada de los marcos cronológicos habituales, modernos, metafísicos o falogocéntricos, para los cuales no deja de ser un problema una doctrina ciertamente oscura y difícil de aprehender racional o causalmente: "The cosmological argument for eternal recurrence can be seen as subversive of both teleology and mechanisism in that it can be shown to be no less plausible in the very same terms" (Wood, 2001, p. 18).

Específicamente la doctrina del eterno retorno, siempre inquietante y deliberadamente "subversiva" quiebra la plantilla lineal de temporalización: "Eternal recurrence puts in question the assumed self-contained status of its units [seriality] 'nows' and their fundamental successivity. For as well as being located on a horizon axis of succession, each unit also appears to be a member of a vertical series of repetitions" (Wood, 2001, p. 19).

La repetición, entonces, involucra no solo una serie horizontal de "ahoras" en sucesión, sino un eje vertical ${ }^{87}$ en que esos momentos hallan una suerte de intensidad específica que los aleja de la homogeneidad. Cada "ahora" está implicado también en un tipo de repetición no mecánica o no cuantificable, ese "esplendor" es el que rescata el eterno retorno, por ello lograr o alcanzar [attain] el super-hombre es un asunto de tiempo, de tiempo intensivo y rizomático, no de espera paciente según los relojes o de acuerdo a un momento fijado en los cronogramas: "attaining" the übermensch for one moment and of the immortal moment... in which I produced return (Wood, 2001, p. 21, cursivas añadidas).

Se trata, entonces, de una temporalidad extática que cuestiona de manera radical el tiempo frío y ajeno del calendario como organización "objetiva" o incluso "científica" de los acontecimientos. Una temporalidad paradójica y onírica que rinde tributo - como sostenía Carl Pletch - al descubrimiento "en sueños" del eterno retorno: "It is very characteristic that Nietzsche discovered the central idea of his philosophy of time - and thus the whole of his philosophy - namely, the concept of "eternal return of the same" in a dream. It is this dream and eternal recurrence which gave unity to his thoughts on 'the times', 'history', and 'time"' (Pletsch, 1977, p. 31).

Ya en el segundo excurso ("La hora de aparecer") se exploró ese carácter onírico de la "aparición" del eterno retorno, lo clave aquí va a ser el pasmo [experience of exhilaration] de tales momentos, de los cuales va a decir David Wood que son los

87 "The addition of a depth to each moment redirects attention away from relations of succession toward the possibilities of intensification. Part of what makes for the experience of exhilaration is that they project their own ecstatic affirmative vision onto the rest of time" (Wood, 2001, p. 21). 
únicos que se repiten infinitamente: "only this affirmative rapture wills itself enough to will its own infinite repetition. Only this total self-affirmation wants itself more and again" (Wood, 2001, p. 22).

No son los fríos y monótonos instantes de una vida sin relieve los que se repiten, a pesar de la formulación contundente de que en el eterno retorno tanto los momentos considerados buenos, creativos o lúcidos como los miserables volverían de idéntica forma. La dimensión profunda o mejor intensiva de la temporalidad del eterno retorno hace una diferencia significativa: "the eternal recurrence is neither a mechanical, nor a "logical", nor a "mathematical" repetition. Rather, it can exercise a selective power [...] only "active becoming" "has being" in the sense of embodying the principle of eternal recurrence" (Wood, 2001, pp. 25-26).

Esta lectura claramente solo es posible al apartarse de marcos lógicos como el "principio de identidad", ya que en Nietzsche la formulación de su doctrina capital se escurriría en los intersticios de aprensiones lógicas que precisamente son transvaloradas, des-construidas o parafraseadas paródicamente; quizá buscando que su "reinscripción" dentro de la tradición metafísica del tiempo genere efectos de extrañeza capaces de desencaminar la linealidad cronológica usada como referente en los relatos de los historiadores, enrareciendo en términos del devenir una arborescente imagen temporal anclada aún en el "ser" y no en su movilidad inestable (quizá rizomática) como "devenir" :

the function of eternal recurrence is to allow the reinscription of becoming within the discourse of metaphysics in a way that undermines that discourse. The point is that becoming demands a quite "different" logic of identity to that of being. (Wood, 2001, p. 29)

La anticipación de esa lógica temporal diversa a la del "ser" y la valoración cronométrica del instante va a ser lo que ciertos autores como White, Ankersmit, Jenkins o Elisabeth Ermarth buscan al hablar de una "historia posmoderna". En tal sentido James A. Winders, miembro del departamento de historia de la Appalachian State University en Boone, Carolina del Norte, va a extraer las consecuencias que a nivel de escritura de la historia tienen tales temporalidades y narrativas "posmodernas":

As postmodern culture multiplies temporal possibilities, and as long overdue attention comes to groups denied their place in standard historical narratives, it will become impossible and undesirable to cling to a conventional sense of linear chronology. Just as attention to women or to minority cultures calls conventional historical periodization into question, previously marginalized groups of topics cannot simply be inserted into a chronology that made sense only through universalizing the experience of a narrow range of humanity. (Winders, 1993, p. 7)

Nuevamente se está en presencia de las consecuencias políticas de una crítica radical a la temporalidad moderna y sus modos de tramar el relato histórico. Es interesante en especial cómo las temporalidades de grupos marginados, excluidos o secundarizados 
pueden tener lugar en narrativas posmodernas. Como resultado del trabajo genealógico quedan expuestas sensibilidades temporales no encasillables en los marcos lógicos de la modernidad capitalista, sobre todo al estallar la aparente unidireccionalidad del metarrelato histórico asociado a la idea de "progreso" en Occidente.

Multiplicidades irreductibles al tiempo como significante despótico hormiguean y reclaman modos de tramado histórico nuevos, "desengancharse" de la cronología lineal convencional [conventional linear chronology] no es solo un gesto con connotaciones epistemológicas, sino directamente políticas al relacionarlo con identidades "rizomáticas" y modos de vida ajenos a los estándares de universalización de la historia tradicional:

Better the labyrinth than the perfectly proportioned pyramid of learning: if our postmodern culture helps us to realize the multiple narratives and myriad temporalities at work in history, then we should be able to realize as well that there is more than one path to the acquisition of historical knowledge and understanding. Experiencing history is an inherently disorderly process. Much of mental life, often its most creative aspects is disorderly. (Winders, 1993, p. 3)

Ese desorden no es algo que deba ser ontologizado por suerte de alguna metanarrativa temporalizante, sino que conoce sus propios ritmos anticíclicos o acausales. Tal aparente "falta de orden" puede ser celebrada como línea de fuga al exceso racional derivado de la epistemología de la modernidad capitalista. El artículo de Winders que viene analizándose se focaliza en obras de arte moderno que buscan dislocar las continuidades temporales, particularmente a partir de un epígrafe extraído de Esperando a Godot de Samuel Beckett:

Vladimir : What was I saying? We could go on from there.

Estragón: What were you saying when?

Vladimir: At the very beginning.

Estragon: The very beginning of WHAT?

Vladimir: This evening... I was saying... I was saying...

Estragon: I'm not a historian.

La parodia al trabajo de un historiador que da por descontado lugares de inicio o hechos inaugurales como algo dado es evidente, con lo que se sobreexpone el sinsentido básico de dotar de valor metafísico construcciones como la idea de tiempo y todas las marcas cronológicas que le son propias. El llamado de obras como la de Beckett, incluidos los perturbadores y fascinantes monólogos de sus tres grandes novelas Molloy, Malone muere y El Innombrable, es a librarse de tales mecanismos regularizadores de la experiencia, su absurdo y el error de seguirlos como autoevidentes o epistemológicamente fundados. 
Pedir "orden" sigue haciendo parte de la tentativa de ubicación unilateral de los acontecimientos en maquetas cronológicas que han perdido valor de verdad a priori, como la frase de Vladimir que busca hacer inteligible su discurso a partir de un origen, un punto de comienzo desde el cual temporalizar los hechos. Estragon acaba renunciando a la empresa argumentando que él no es un historiador, a la vez que resuena en el ambiente la ironía de especificar tales puntos de arranque como algo ontológico y no como convenciones políticamente mediadas:

the demand for more order and the demand for a master narrative go hand in hand. The sense of play and joyous affirmation that can animate the learning process can best be encouraged by an openness to alternative narratives and histories. (Winders, 1993, p. 3)

Tales narrativas alternativas son posibles gracias a un pensamiento tan absurdo e intrincado como el expuesto en la narrativa de Samuel Beckett, o tan paradójico como el eterno retorno de lo mismo en el sentido asumido en este capítulo. Desvinculándolo de exigencias propias de la metafísica de la presencia o del principio de identidad de la racionalidad moderna, el eterno retorno de lo mismo alumbra dimensiones temporales extáticas o desmedidas en las que caben intensidades y modos de secuenciamiento divergentes.

Todo esto implica un modo de consciencia apartado de la naturalidad otorgada a las historias del pasado: "so we fall into the least common denominator of linear chronology, and in the process, we produce a fictional narrative: "First this happened, then this happened. Later a lot more happened" etc., etc., etc. We create these fictions to reduce the complexity of our task and because it comforts us and reassures us that we really know what we're talking about" (Winders, 1993, p. 2).

En este lugar aparece una disyuntiva clave, como Estragon en la cita de Beckett, muchos estarían tentados a desligarse de los debates acerca de la idea de "tiempo histórico" por considerarlas exclusivas del campo de ejercicio profesional de los "historiadores", parte de su experticia y de su identidad profesional. Esto implicaría que solo aquellos dotados de entrenamiento historiográfico estarían en capacidad de entrar en estas discusiones o de sacarle provecho a estas reflexiones, o como si solo fuera competencia de la Historia y el cuerpo de eruditos y académicos que la conforman un análisis del estatuto del tiempo y la naturaleza del relato sobre los eventos del pasado. Respecto a esto Elisabeth Ermarth nos abre una perspectiva diferente:

Like most of the people you meet in the grocery store or on the underground I am a practicing historian: practice is at stake. History is not an academic preserve; it is the mental system by which most of us explain things to ourselves. (Ermarth, 2012, p. 4)

Esta aseveración incluida en la reseña que la historiadora hace del libro de 2011 The future of History de Alun Munslow, cuya teoría de la historia será objeto de discusión en el siguiente apartado, parece ahora iluminadora por su simpleza: todo ser humano en la incesante tarea de explicarse el mundo parte de unas presuposiciones 
sobre el pasado, todos los sujetos comparten la compulsión por la explicación histórica, trátese de grandes periodos o del día a día más cotidiano.

Tanto en las estructuras de larga duración como en la minucia del "everyday life" se requieren sistemas categoriales para ajustar el devenir de los acontecimientos. Que esto sea dicho por una historiadora interesada en proponer nuevas configuraciones para el relato histórico y nuevos modos "rítmicos" o "intensivos" de temporalidad no deja de resultar significativo.

Se trata de una presunción del sentido común expresada con lenguaje académico en medio de un debate sobre el agotamiento de los recursos explicativos de la modernidad, lo que se lee en la frase de Ermarth es una tentativa por reubicar la discusión más allá del ámbito de especialidad propio de los departamentos de historia. Ella misma en su reciente libro sobre la historia en la llamada "condición discursiva" nos dice: "the departure from modernity signals a tectonic change radical enough to suggest that even the tools of thought change if we are to keep up with ourselves in any vital or creative ways" (Ermarth, 2011, p. xii).

Hablar de "condición discursiva" es un modo de situarse en el contexto de la famosa "condición postmoderna" inicialmente caracterizada como la condición del saber en las sociedades informatizadas por Jean François Lyotard -a finales de la década del setenta del siglo XX-. La peculiaridad del llamado de Ermarth tiene que ver con las herramientas epistemológicas o cognitivas [tools of thought] del historiador con posterioridad al giro lingüístico, es decir, en un contexto donde la naturaleza lingüísticamente construida de la "verdad" o de las identidades sociales no es algo escandalizante o exótico.

Como ejemplo de lo anterior, y siempre analizando casos de narrativa literaria, Ermarth entra a considerar las posibilidades abiertas por un relato de ficción de Jorge Luis Borges:

Borges's histories provide an almost magical approach to reconceiving time as a multidimensional web of plural realities. For example "The Garden of the Forking Paths [El jardín de senderos que se bifurcan]", outline a mortal competition: on the one hand, the time of history and project and its irreductible individual subject, and on the other hand, a new kind of time as an "invisible labirynth" in a text where rhythm and multivalence prevail. (Ermarth, 2011, p. 103)

El tiempo como red multidimensional de realidades plurales [multidimensional web of plural realities] nos acerca a ideas del mismo trabajadas anteriormente a partir de autores como James Winders, Keith Jenkins o el mismo Hayden White, para quien es la narrativa histórica la que acota de ese infinito multívoco un horizonte cronológico preciso. Ni que decir de la idea nietzscheana de voluntad de poder, en la que tal pluralidad halla su medio de expresión y transformación permanente.

Atisbar dentro de la literatura herramientas útiles en la tarea del historiador, entra en particular y fecunda resonancia con ideas de la metahistoria de Hayden White. 
Además porque el anterior segmento del libro "History in the discoursive condition" elabora la distinción que pueda plantearse, tanto a nivel de teoría de la historia como de la experiencia cotidiana, de tramar un relato de lo vivido entre la ficción y la historia "realmente acaecida".

En el cuento de Borges que se alude, el contrapunto entre la historia de un bombardeo durante la segunda guerra mundial y la virtualidad de variaciones no oficiales de ese "hecho" es tematizado de manera explícita. No con ánimo de comentar los pormenores de la sobrecogedora idea de un "laberinto de tiempo", quizá asociable al eterno retorno nietzscheano, aquí apenas se señalará el carácter abierto, inconcluso y profundamente imaginativo de tal idea.

Allí donde la coexistencia de diversas configuraciones temporales no es rechazada en favor de lo "verdaderamente ocurrido", sino potenciada en dimensiones de la temporalidad y de la consciencia históricas francamente ajenas y apabullantes, incluso enloquecedoras como le ocurrió a Nietzsche con su monstruoso "eterno retorno".

Volviendo a la necesidad de revisar las herramientas cognitivas del historiador, el autor de "Deconstructing history" había aseverado: "there are many reasons, then, for believing we live in a new intellectual epoch - a so called postmodern age- and why we must rethink the nature of the historical enterprise to meet the needs of our changed intellectual beliefs and circumstances" (Munslow, 1997, p. 12). Nuevamente tratando de eludir la esterilidad de discusiones acerca de la naturaleza de la llamada posmodernidad, derivadas de seguir confrontando posibilidades de pensamiento insospechadas - como las abiertas por una obra como Así habló Zaratustra- con términos, marcos teóricos y metodologías modernas, Allun Munslow aporta una valiosísima clave interpretativa:

I prefer to think of our present intellectual age not as something that came after (hence post-) but rather A TRANSMUTATION OF MODERNISM, "postmodernism" has often been deployed to mean the arrival of a new set of conditions for knowing when it seem more appropriate to say modernism has now become fully aware of its own in-built critique of knowing. (Munslow, 1997, p. 12, mayúsculas fuera del texto)

La posmodernidad definida (experimentalmente) como transmutación -en el sentido nietzscheano- de los valores y presupuestos de la modernidad parece mucho más interesante que seguir pensándola a partir de horizontes modernos como la linealidad histórica y la secuencialidad de los hechos. Se intuye que así se desafían las compartimentalizaciones de época acostumbradas a situar en sucesión los grandes periodos históricos.

El prefijo "post" funcionaria como un shifter metairónico encargado de subvertir el significado atribuido usualmente a lo "post". Sin perder de vista los contextos de aceleración mediática y publicitaria que fabrican la idea de que lo último es necesariamente más epistemológicamente sofisticado que lo anterior o vetusto. En el caso de los autores aquí referenciados, como para Nietzsche mismo, venir "después" 
- como respecto al super-hombre- no necesariamente implica desconocer la coexistencia de devenires, reflujos, contraflujos y resignificaciones retrospectivas de la temporalidad, así como la imbricación paradójica y casi onírica de órdenes discursivos heterogéneos.

Así las cosas, se persiste en en llamar la atención sobre las críticas realizadas a la idea de tiempo histórico, desde la llamada "deconstrucción de la historia" (Munslow) o la "transvaloración de la idea de tiempo" (Wood) que sigue funcionando como plantilla única de legibilidad en el oficio del historiador.

\subsection{ASÍ HABLÓ ZARATUSTRA, DEVENIRES Y NUEVAS INSOSPECHADAS TEMPORALIDADES}

En un sistema multilineal, todo se produce al mismo tiempo

(Deleuze-Guattari, 1997, p. 296).

Se retoma en este cuarto y último apartado la formulación insinuada en el segundo acápite sobre "nuevas formas de la temporalidad". Para ello la argumentación se dejará encantar por los ritornelos, las derivas y devenires Deleuze-Guattarianos, sus líneas de fuga y multiplicidades desterritorializantes. Revisando de esta suerte algunos textos que en los últimos años han abordado específicamente la obra Así habló Zaratustra, su narrativa y la filosofía del tiempo allí desplegada (Rosen, 1995; Seung, 2005; Loeb, 2010).

Un temprano texto de Carl Pletsch, publicado en History and Theory, sigue siendo medular en una consideración sobre la historia y la filosofía del tiempo en el pensamiento de Nietzsche. Allí se despoja su obra de cualquier marca trascendental o teleología histórica: "since all moments are equal in the eternal becoming and passing away, history cannot have any direction and certainly not that of progress" (Pletsch, 1977, p. 37).

A pesar de la posibilidad de una lectura secuencial sobre el advenimiento del super-hombre, extraída, por ejemplo, del prólogo de Zaratustra en que se diagnostica el predominio de la peste del "último hombre", su pequeñez y la insustancialidad de su horizonte de vida (que no cuesta mucho asociar al estado actual del hombre consumista en la "sociedad del espectáculo"), la "llegada" del super-hombre no puede simplemente situarse "después" de que termine su reinado, tampoco puede ser anticipada de acuerdo a la cuadrícula sin sobresaltos de una secuencialidad cronológica estable.

La imagen de hombre como "puente" entre el animal y el super-hombre, discutida en el primer capítulo, podría dar lugar a un malentendido semejante. Sin embargo, el análisis de Pletsch resuena con las intuiciones de David Wood al apartarse de una lectura lineal de la filosofía del tiempo en Nietzsche. Desde las consideraciones 
intempestivas está claro que la idea de "progreso" no es algo que lo seduzca, por lo que habría que buscar en una concepción diversa de la temporalidad el marco adecuado en el que situar su doctrina del eterno retorno y el momento, extático o ensoñativo, quizá, de la aparición del super hombre.

Ese marco temporal definitivamente está lejos de metarrelatos como el de Nación o grandes referentes abordados ahistóricamente como el de "humanidad" u otros semejantes: "the possibility that the concept of species, mankind, can give historical significance to nations, institutions, or human beings was from the start unacceptable to him [Nietzsche] [...], the historical concept of "development" is drained of its philosophical content until the flow of time becomes no more than a succession of moments" (Pletsch, 1977, p. 39).

La preferencia interpretativa de Pletsch lo hace desconfiar de cualquier idea reguladora que quiera alzarse con pretensiones de validez incuestionable, como discípulo escogido de Heráclito, según se autoproclamara Nietzsche, e incluso heredero y epígono del dios Dionisio, de acuerdo a su elaborada fabulación identitaria, el autor de Así habló Zaratustra se ha despojado de la fe y la confianza en ídolos que para él yacen defenestrados en el derruido jardín de las efigies modernas. Deleuze y Guattari sitúan allí el carácter intempestivo de su escritura:

La frontera no pasa entre la historia y la memoria, sino entre los sistemas puntuales ("historia-memoria") y los agenciamientos multilineales o diagonales, que no son en modo alguno lo eterno, sino devenir, un poco de devenir en estado puro, transhistórico. No hay acto de creación que no sea transhistórico, y que no coja a contrapelo, o no pase por una línea liberada" (Deleuze- Guattari, 1997, p. 295).

Las velocidades de aparición y desaparición de tales "agenciamientos" ya comentados a propósito de la "memoria corta" es lo que interesa aquí. Los llamados "sistemas puntuales" esquematizan aquietando las inagotables derivas del devenir, a partir de aparatos de captura molar como eran para Nietzsche los estudios históricos estériles e hipertrofiados a finales del siglo XIX en Alemania.

Analizando con prudencia la extraña expresión "transhistórica", aquí se entiende como un modo de temporalidad que se resiste al apresamiento de los modos de sedimentación y coagulación de la "Historia". Lo importante, según ha sido expuesto, son las velocidades de toma de consistencia de los agenciamientos, dispositivos o agrupaciones puntualizadas. Para Deleuze y Guattari los elementos de su narrativa no son identidades, objetos o épocas históricas, sino los vectores y su trenzamiento, las diagonales y los coeficientes de aceleración que van a hacer posible la aparición de tales "identidades, objetos o épocas históricas", en particular respecto al flujo y velocidad percibibles en la idea de tiempo histórico y expresados en la obra Así habló Zaratustra de Nietzsche.

Específicamente sobre la filosofía del tiempo y el valor de la historia, los autores de Mil mesetas sostienen: "Nietzsche opone la historia, no a lo eterno, sino a lo 
subhistórico o a lo suprahistórico: lo Intempestivo, otro nombre para la haeccedidad, el devenir, la inocencia del devenir (es decir, el olvido frente a la memoria, la geografía frente a la historia, el mapa frente al calco, el rizoma frente a la arborescencia)" (Deleuze-Guattari, 1997, p. 295).

El sistema de distinciones clásico que opone lo temporal y lo eterno se muestra insuficiente, ya que en Nietzsche la línea de fuga frente a la historia y las miserias de la cultura de su época no es lo eterno, sino lo intempestivo. Una oscilación indecidible en los modos de percepción histórica del momento, como un temblor inclasificable y claramente por fuera de los marcos de legibilidad mainstream de finales del siglo XIX, las consideraciones intempestivas de Nietzsche hacen una crítica al horizonte temporal con recursos interpretativos fuera de su marco de referencia, ese es el sentido que Deleuze y Guattari dan al pensamiento intempestivo de Nietzsche.

Lo anterior significa situarse más cerca del esplendor de un acontecimiento incontenible en las sedimentadas capas de temporalidad del positivismo histórico. El super-hombre y las reflexiones siempre intempestivas que lo acompañan y hacen posible resbalan en los intersticios y el "entre-dos" de los horizontes modernos de legibilización temporal.

El rizoma, el mapa y la geografía no son ubicables en el reverso lógico de sus pares (el árbol como principio cognitivo, el calco como reproducción de lo diferente sojuzgada a un modelo y la historia como instancia de congelamiento de las velocidades ontogenéticas y mutables), más bien funcionan como gatilladores o potenciadores de nuevas e insospechadas configuraciones en la organización estratificada de los vectores; siempre entre los grandes agenciamientos maquínicos y dispositivos colectivos de enunciación.

El carácter intersticial y umbrátil del pensamiento de Nietzsche es retomado por Stanley Rosen en su análisis de Así habló Zaratustra titulado The mask of enlightenment: "one has to navigate between the Scylla of aesthetical obtuseness of overinterpretation and the Charybdis of underinterpretation or failure to penetrate what has been intentionally masked" (Rosen, 1995, p. XVI).

Aquí también se percibe la dificultad de situarse sin más de uno u otro lado de las dicotomías fundantes de la imagen del pensamiento de la modernidad racionalista. Llama la atención en el caso del análisis de Rosen, la metáfora de Escila y Caribdis tomada de la mitología griega. Como dos gigantescos monstruos marinos, estos guardianes del fin del mundo implican la doble captura de una máquina de significación que aplana la multivocidad o equivocidad propia del acontecimiento al etiquetarla según binariedades dadas por descontado. En este caso el acontecimiento es el pensamiento de Nietzsche sobre el tiempo y la historia. La enseñanza, entonces, es precaverse de sobreinterpretarlo caprichosamente a la vez de infra-interpretarlo exegética o dogmáticamente. 
Como ejemplo del tipo de consciencia que exige el Zaratustra a sus lectores, Rosen habla de un "estado hipnótico" [hypnotic state] generado por su lectura. Es decir, el texto mismo desposiciona los modos perceptivos habituales haciendo uso de técnicas narrativas delirógenas o psicoalterantes: "there is a great deal of repetition in Zarathustra, in part no doubt for the practical purpose of inducing a hypnotic state in the potential disciple" (Rosen, 1995, p. XVII).

Tal fascinada desfascinación delirógena o hipnótica se lograría mediante cierto uso de la repetición. Aquí estamos frente a algo que va a ser medular en la interpretación de Paul Loeb The Death of Nietzsche's Zarathustra: la idea según la cual el mismo texto ejemplifica y materializa las ideas de las que habla haciendo uso de su narrativa.

Esto significa que la repetición y el carácter intrincado, laberíntico o enmarañado de las aventuras de Zaratustra expresan directamente la doctrina del eterno retorno. No solo hablan de él o lo alegorizan de algún modo, como explicándolo en el plano intelectual, sino que hacen el mapa, no calcan un modelo que estaría en otro lugar - trascendente o universal-, lo ponen en obra en los caminos indecidibles que traza Zaratustra en el acto de experimentarlos, no interpretando un modelo que permanecería oculto o inaccesible - metafísicamente- .

Podría decirse que la idea del eterno retorno se siente en la lectura a manera de ritornelo de Así habló Zaratustra, mareante y repetitiva. Por ello, se dice que "Nietzsche does not present argued doctrines in Zarathustra. He is not providing us with a philosophical system as an alternative to the traditional systems of the great Western philosophers. To the contrary, Nietzsche offers us an alternative to philosophy" (Rosen, 1995, p. 8).

La lectura de Rosen, así las cosas, ritma magníficamente con las intuiciones de los autores de Mil Mesetas. Entrando en devenir con Deleuze y Guattari, para quienes la temporalidad intensiva y aiónica de Nietzsche invita a elaborar y constituir una nueva imagen del pensamiento. De esa suerte Rosen con su "Máscara de la ilustración" afirma una transgresión de las normas del género filosófico tradicional al considerar una obra como Así habló Zaratustra ${ }^{88}$.

88 En el extremo opuesto podemos citar la sistemática, despoetizada, gris y plana lectura de Peter Berkowitz (1995, pp. 163-279) sobre Así habló Zaratustra, donde se celebra el fracaso de un Zaratustra ridículo y "cómplice de la degradación del hombre superior" (ibid., p. 272). Su postura puede sintetizarse en esta afirmación: "el sorprendente logro de Así habló Zaratustra es mostrar una imagen coherente y convincente de la incoherencia y la inviabilidad de las esperanzas supremas de Zaratustra" (ibid., p. 167). Sin ocultar la evidente molestia que los giros poéticos y narrativos le causan, Berkowitz lee el Zaratustra como quien lee un manual de filosofía, por ello se disgusta tanto con el aspecto literario y estético de la obra, su análisis, por lo demás minucioso, declara preferir Más allá del bien y del mal y siempre en tono de burla y descalificación extrema se refiere al estilo y los modos tropológicos de construcción del Zaratustra. Consideramos esta interpretación un ejemplo notable de lectura inadecuada, Berkowitz busca en Zaratustra algo que jamás se propuso Nietzsche, y se niega a considerar el libro más allá de la presentación clara, "viable", concisa o eficaz de las ideas. El carácter paradójico y experimental de la obra, que desde la atmósfera de un "tempus ex machina", pensamos, es lo más valioso de ella, Berkowitz lo ignora o lo rechaza abiertamente. Si alguna vez Nietzsche pensó en un dogmático recalcitrante o un filisteo de la cultura, ese sería Peter Berkowitz. 
Esta idea es patente en la anterior cita, donde no se ubica a Nietzsche como alternativa a los sistemas filosóficos existentes, como reduciendo su riqueza al tramado de un sistema filosófico más, comparable a las grandes elaboraciones de Hegel o Kant por ejemplo. Sino que lo que él ofrece es algo distinto a la filosofía en sentido convencional, desautorizando las categorías más básicas de su discurso, especialmente en lo tocante a la idea de "tiempo" como a priori o plantilla hermenéutica primigenia. Nietzsche imagina a través de Zaratustra un verdadero "devenir", la inocencia de un devenir no mapeado según las coordenadas de espacialización y decodificación propias del pensamiento histórico moderno.

Por eso, como imágenes confrontadas en un espejo sin saber cuál es la original y cuál la copia, se plantea la indecisión respecto a la caracterización de una figura como "verdadera" y otra como descaecida simulación (ontológicamente minusvalorada). Se proponen dos modos de la temporalidad: Cronos y Aión, para el primero y el plan de trascendencia que lo organiza y estratifica de manera unívoca, aún es válida la distinción entre original y copia, ayer-hoy y mañana como referentes claros e incontrovertibles. Pero para la temporalidad del Aión, fundida en un plan de consistencia pre-personal e intensivo las cosas funcionan bien diferente:

Incluso cuando los tiempos son abstractamente iguales, la individuación de una vida no es la misma que la individuación del sujeto que la lleva o la soporta. Ya no es el mismo Plan: plan de consistencia o de composición de las haecceidades en un caso, que solo conoce velocidades y afectos, plan completamente distinto de las formas, de las sustancias y de los sujetos en el otro caso. Y no es el mismo tiempo, la misma temporalidad. Aiôn, que es el tiempo indefinido del acontecimiento, la línea flotante que solo conoce las velocidades, y que no cesa a la vez de dividir lo que ocurre en un déjà la y un pas-encore-là, un demasiado tarde y un demasiado pronto simultáneos, un algo que sucederá y que a la vez acaba de suceder. Y Cronos, que, por el contrario, es el tiempo de la medida, que fija las cosas y las personas, desarrolla una forma y determina un sujeto (Deleuze-Guattari, 1997, p. 265).

Por eso, Zaratustra escenifica un particular tipo de ilusión que podemos ver desde Cronos como aparato de captura, o con la inocencia indecidible y plural del aión: "the particular chapters of the work [Zarathustra] are critical commentaries on aspects of European civilization. But the work as a whole is itself an illusion: the illusion that Nietzsche is in fact Zarathustra, a Persian and the founder of the epoch of good and evil" (Rosen, 1995, p. 16).

Situarse en esa ilusión a la velocidad operativa de un plan de consistencia hiperintenso, real y virtual a un tiempo, implica percibir el tiempo flotante y múltiple del eterno retorno: "Boulez distingue en la música el tempo y el no tempo, el 'tiempo pulsado' de una música formal y funcional basada en valores, y el 'tiempo no pulsado’ para una música flotante, flotante $y$ maquínica, que solo tiene velocidades o diferencias de dinámica" (Deleuze-Guattari, 1997, p. 265). 
Los comentarios críticos a varios aspectos de la "civilización europea" [European civilization] no solo denuncian conceptual o intelectualmente sus imposturas, sino que son inmediatamente escenificados en partes específicas de Así habló Zaratustra, como quien pone en obra las líneas de fuga y los vectores desterritorializantes en la escritura misma de la historia, en el tramado de la narrativa. Generando así esa rara atmósfera de "tiempo no pulsado" capaz de poner inmediatamente en contacto con la temporalidad intensiva del eterno retorno de lo idéntico.

Así las cosas, este tiempo del Aión expresado en la narrativa de Así habló Zaratustra (y no solo aludido o referido en su encadenamiento argumental) construye sobre la marcha un "modo de temporalidad" diverso al derivado de la onto-teología y la metafísica de la presencia reinante en la modernidad, con sus correspondientes derivaciones en los diversos estilos y escuelas historiográficas: "en resumen, la diferencia no se establece en modo alguno entre lo efímero y lo duradero, ni siquiera entre lo regular y lo irregular, sino entre dos modos de individuación, dos modos de temporalidad" (Deleuze-Guattari, 1997, p. 265).

Puede intersecarse aquí la interesante lectura que Thomas Seung hace de la obra capital de Nietzsche, para la cual operaría una sublimación o transustanciación del personaje Zaratustra al final del libro que corre pareja con la des-construcción y sublimación de la idea misma de tiempo histórico: "the most important transformation, however, has taken place in Zaratustra himself. Like Lucius, he has been reborn. As we noted earlier, he died from the temporal world and was reborn as a heavenly child in the eternal world" (Seung, 2005, p. 334).

Recordando a Lucius, el protagonista del "Asno de oro" de Apuleyo, quien también sufriría una transmutación final, no solo recobrando su primitiva forma humana sino accediendo a un modo de comprensión de la historia radicalmente diversa y no anticipable a lo largo de las aventuras del libro, la figura de Zaratustra también sufre la transformación que se evidencia luego de padecer la revelación pesadillesca del eterno retorno de lo idéntico.

Con la aparición del "signo" - el león riente y la bandada de palomas-, Zaratustra llega a ser un iluminado comparable a aquel pastor que escupió la pesada serpiente negra que se había enroscado mordiendo el interior de su garganta (De la visión y del Enigma, Nietzsche, 2006, p. 232), llega a reír como un iluminado.

De allí que respecto a las múltiples transmutaciones de Zaratustra y los demás personajes a lo largo de la obra, Seung se centre en aquella en que este "renace" como el niño [heavenly child] luego de haber pasado por ser un camello y un león sucesiva e intensivamente (no causalmente). Respecto a la críptica afirmación de Seung "eternal world", se entiende no desde la metafísica del cristianismo, sino de acuerdo a las coordenadas flotantes e indecidibles entre un "ya pasó" y un "aún no pasado" que se desplazan a lo largo de un modo de temporalidad que Deleuze y Guattari caracterizan (y tornan imperceptible) como Aión. 
Acceder a la temporalidad del Aión es la "épica del alma" que escenifica Así habló Zaratustra en el estudio de Seung: "Zarathustra's psychological kingdom begins with the assembly of his higher men, who represent his old self, and ends with the assembly of his new children, who represent his new self" (Seung, 2005, p. 336). Este nuevo "self", por cuenta del cambio en el estatuto ontológico de su modo de individuación (ya no dentro del repertorio caracterológico o abanico identitario de un tiempo cronológico, o aún preso de constricciones "modernas" a la hora de elaborar el relato histórico) se asocia aquí a la temporalidad del Aión, a la constitución de un "bloque sonoro" o devenir.

El modo de entrar en resonancia con esa línea amorfa de desterritorialización cronológica sería ese "drama del alma" como comedia y narrativa paródica de Nietzsche en la cuarta parte de Así habló Zaratustra: "The baffling comedy of his higher men reflects the complex character of his soul. It is the drama of his soul" (Seung, 2005, p. 338). Ahora bien, la siguiente cita explícita o despliega mejor las posibilidades e implicaciones del mencionado "bloque sonoro" o línea de devenir:

pues bien, en esa línea transversal que realmente es de desterritorialización, se mueve un bloque sonoro, que ya no tiene punto de origen, puesto que está ya siempre en medio de la línea, que ya no tiene coordenadas horizontales y verticales, puesto que crea sus propias coordenadas, que ya no forma una unión localizable entre un punto y otro, puesto que está en un "tiempo no pulsado": un bloque rítmico desterritorializado, que abandona puntos, coordenadas o medida, como un barco a la deriva que se confunde con la línea, o que traza un plan de consistencia. (Deleuze \& Guattari, 1997, p. 296)

El plan de consistencia se diagramatiza, no se calca según escalas y mecanismos proyectivos ya dados, intensivamente en la estructura narrativa de Así habló Zaratustra, junto con sus velocidades y líneas de fuga, como se sostenía más arriba, esta es la idea clave tanto en la lectura de Stanley Rosen como en el más recientemente publicado estudio de Paul Loeb sobre el Zaratustra de Nietzsche:

Just as the lives and actions of the protagonist in Wagner's Ring are meant to dramatize his insight into the reality of eternal change, so too the life and actions of Zarathustra are meant to dramatize what Nietzsche thinks is the deeper reality of eternal repetition. Thus, the fictional protagonist of Nietzsche's artwork does not relate to some abstract concept of eternal recurrence, but rather to the reality of eternal recurrence that is embodied in the structure of the narrative itself. (Loeb, 2010, p. 6)

Considerada como la tesis central del libro de Loeb, se analizará aquí para intentar concluir este cuarto acápite a partir de los ritornelos y devenires DeleuzeGuattarianos. La hipótesis será que tanto Mil Mesetas como Así habló Zaratustra son líneas de fuga que operativizan en la escritura misma aquello de lo que hablan, como se lee en la anterior cita del libro de Loeb. Es la realidad del eterno retorno la que es experimentada en la narrativa de la obra. Zaratustra no elucubra de manera abstracta 
sobre el eterno retorno sino que incorpora sus surcos, pliegues y reiteraciones en la dramatización del personaje como tal, en el armado indecidible y abismal del libro.

Una cita de François Dosse abre una línea de fuga respecto a Mil Mesetas en esa misma dirección, dice el historiador francés en el capítulo 14 de su "biografía cruzada", titulado "Mil mesetas: una geofilosofía de lo político": "Cada meseta tiene una fecha precisa como epígrafe, que remite a un acontecimiento histórico epónimo del capítulo. Es una manera de recordar la importancia del acontecimiento para su filosofía, pero según una lógica que ya no tiene nada de cronológica ni de evolutiva” (Dosse, 2009, p. 316).

La asignación de fechas parodia y descontextualiza deliberadamente las linealidades cronológicas de los historiadores, como cuando se hablaba del arte minimalista o de la estética dadá. En palabras de Marcel Duchamp, se vierte un "disolvente metairónico" o se "anestesia estéticamante" el objeto.

En ese caso se trataba de los conocidos ready made, aquí es la obra histórica misma la que se anestesia con fechas e indicaciones que deslocalizan no simplemente desconociendo las narrativas históricas main stream, sino llevándolas a su absurdo lógico (también recordamos los delirantes diálogos en las obras de Beckett, en el fragmento transcrito de Esperando a Godot o en la hilación argumentativa y paradójica de sus novelas mayores).

La nota 4, en la misma página del libro de F. Dosse dice "Al 20 de noviembre de 1923 sucede el 587 a. C., luego el 28 de noviembre de 1947, el año cero, 1874, 1933..., estas escansiones tienen el efecto de cambiar el tiempo, de desorientarlo, de sacarlo de cualquier axiomática, para que Cronos deje su lugar a Aión" (Dosse, 2009, p. 316 subrayado añadido).

No solo por virtud de su no secuencialidad las mesetas se articulan de una forma-otra respecto a las expectativas de organización de las fechas, consecutivas e ineludibles. Si el Aión presentifica la infinita y fractal subdivisión del presente, se tiene que cada fecha en cuanto marca temporal es susceptible de intensificarse en profundidad como parte de su ambivalente efecto de superficie, como parte de esa verticalidad intensiva que hacía proliferar la neutralidad de cada presente en cualidades insospechadas según se reseñaba en la obra de David Wood.

En este punto son pertinentes los estudios sobre la temporalidad y la filosofía de tiempo en Nietzsche emprendidos por Robin Small. Quien en su obra Time and Becoming in Nietzsche's Thought (Small, 2010) había sostenido "the hidden complexities of his metaphors mirror the complexities of the corresponding conceptual problem". Tal reflejar [mirror] opera no según la lógica del original y la copia, se sostuvo, sino más bien como en el espejo a través del cual Alicia pasa en la segunda parte de sus aventuras (Through the looking Glass, Carroll, 2012).

Lo que se encuentra allí es un mundo solo similar al nuestro en las partes más evidentes y predecibles, pero inimaginablemente complejo y alucinante en lo demás. El punto es que tanto para Small como para Loeb asuntos metafóricos o de estilo 
presentes en la obra de Nietzsche, con particular intensidad en Así habló Zaratustra, no son dimensiones secundarias sino constitutivas de la dramaturgia filosófica de sus ideas. Así ocurre con las etiquetas cronológicas en cada capítulo de Mil mesetas, donde deja de pesar una taxonomía binaria y más bien se percibe la apertura a ese "espacio liso" donde las estrías y cuadrículas del paranoico aparato de captura estatal - e historiográfico- no hallan campo de aplicación ni contexto para el ejercitamiento de su axiomática redundante.

Entonces, no es fortuita la escogencia en Nietzsche de una forma literaria para su obra, ni caprichosa la elección de personajes, contextos de interacción, recursos de ambientación escenográfica y demás utillaje en el armado del Zaratustra: "it is the narrative course of the book's drama that actually shows, manifests, and enacts this thought [eternal recurrence]" (Loeb, 2010, p. 6).

Se trata de estrategias no para la representación del eterno retorno, como quien sigue un libreto que limita y sofoca las posibilidades, sino que en el aire y clima manufacturado por Nietzsche se presenta, sin modelo y sin aparato de captura trascendente, el vacío que es el eterno retorno. La escritura a escala fractal mantiene la auto-similitud con ese gran atractor extraño, no predefiniendo ni anticipando los devenires, sino potenciándolos en cada segmento del drama.

Percibir esas intensidades temporales sirve como criterio de selección para reconocer al super-hombre en su potencial de resistir el eterno retorno: "we can infer that Nietzsche conceives of the superhuman as the kind of species whose discovery and affirmation of eternal recurrence grant it this new kind of power over time" (Loeb, 2010, p. 9).

Poder sin referencia trascendente ni cuadrícula o límite identitario, es la afirmación de un devenir que escapa la gravidez de las máquinas de legibilidad que siguen operando en los relatos del pasado. En tal sentido, se abren posibilidades historiográficas insospechadas, no solo en debates académicos circunscritos al campo de experticia de los historiadores y filósofos de la historia, sino a cada uno en cuanto configurador de la narrativa histórica que es su propia vida, y que responde a herramientas cognitivas y estilos de pensamiento aún deudores de cortes cronológicos que apresan el Aión y reducen el esplendor sin nombre del acontecimiento a un catálogo causal de eventos prediseñados. 


\title{
Excurso 5. Nietzsche, el amante de Mnemosyne
}

\author{
Mais que se passe-t-il quand l'amoureux de Mnemosyne n'a pas reçu le \\ don du récit? \\ $¿$ Quand il ne sait pas raconter une histoire? \\ Quand c'est précisément parce qu'il garde la mémoire qu'il perd le récit? \\ Je ne suis pas en train de sacrifier à la rhétirique d'une invocation à \\ Mnemosyne. \\ (Derrida, 1988, p. 27) ${ }^{89}$
}

1. Amor de diosa olvidada, su tierno aborrecimiento, su tierno, bello en extremo y siempre temible o confuso aborrecimiento, el cuidado que ponemos para que ella pueda olvidarnos, perdonarnos, llegar un día a olvidarnos del todo, dejar de ser amantes de Mnemosyne, amándola y desprendiéndonos más de ella. Recordando insistentemente olvidarla, hundirnos juntos en planos de irrealidad que evoquen su cuerpo ausente, su inmensa ternura, su abominable e inmensa ternura, amando no recordarla, sin querer amando no recordarla, con un cariño monstruoso, energúmeno, el cuidado y todo el amor que ella pone en aniquilarnos, desvanecernos en un mar de angustia, un desagrado sin espesor y sin causa alguna.

Un olvido insistente, maravilloso y desesperante, como tener su nombre siempre en la punta de la lengua, justo en la punta indecisa de la lengua, como si siempre que habláramos nos motivara y nos paralizara ese casi saber su verdadero nombre, amor de diosa olvidada, inolvidable por estarse olvidando en cada fonema, en cada indecible palabra, como si cada vez que decimos algo estuviéramos a punto de mencionarla, nombrarla con precisión, caracterizarla completamente, como si solo faltara un poquito para acordarnos completamente de ella, su nombre sin recordarlo.

Amor de raro silencio, Mnemosyne la impronunciable, en la punta de la lengua su cifra exacta, el vocablo justo, la locución precisa, aquella frase que expresaría perfectamente el amor que sentimos por ella, Memoria justa sin evocarla, el olvido que es el amor que jamás podremos olvidar que sentimos por ella, aterradora inexplícita, el desconsuelo de no poder acordarnos recordando siempre el fastidio sumo de nunca lograr acordarnos, desasosiego supuesto, dolor que siempre se olvida, un desconcierto sin contornos ni objeto preciso.

89 ¿Más qué ocurre cuando el amante de Mnemosyne no ha recibido el don de la narración? ¿Cuándo no sabe contar una historia? ¿Cuándo pierde la narración precisamente porque conserva la memoria? No estoy ofreciendo una invocación retórica a Mnemosyne. 
Amor de recuerdo ambiguo, donde lo primero que no se sabe es qué es lo que se ama, si es ella o por su nombre se trata de otra persona, lo primero o segundo que se cuestiona, amándola para devastarla, para seguir devastándola mientras se pretende ubicarla, identificarla de alguna forma, consolidarla al desvanecerla, corresponderle todo el vacío y el horror que ella nos inspira, memoria de fuego absurdo, su disolución inconclusa, deseada inconclusa y luminosa de pura angustia.

Para continuar siendo amantes de Mnemosyne, revitalizando la imposibilidad constante de recordarla, en cada palabra que nos inspira olvidándola y rindiéndole un impedido homenaje, el amor tierno y detestable que nos despierta, al que correspondemos urgidos por una fascinación que no deja de repudiarla, convertida en terrible Dómina, desaforada y caprichosa Señora, luz de toda ternura, desde el comienzo indomable.

Así nos pierde, amándonos sin descanso, así nos desahuciamos de su presencia, figura de amor más puro y fuente de toda desesperanza, acordarse de ella al burlarla, al esquivarla altaneramente, decididamente pero siempre sin darnos cuenta, si al menos se supiera de quién se trata, porque estando en las narices es nebuloso el hilo conductor de sus frases, en la punta de la lengua cada vez que hablamos o callamos para nombrarla.

Poder nombrarla, maldecirla de alguna forma, amor que nunca se olvida, haciendo de la mudez o el tartamudeo medios expresivos idóneos y execrables para aludirla, intentos que no llegan a rozarla siquiera, acariciarle su esplendor de inmencionable angustia, el rechazo que suscita en nosotros y el encanto de poder evocarla en cualquier momento, con la frase que menos pensemos o el nombre que creíamos olvidado, rogándole aniquilarla, rezándole que se destruya en nuestras palabras, que venga a quebrarse en estos fraseos.

Amor de memoria rota, la dulzura de un abismo tan corrompido, su tierno aborrecimiento, corresponderle el orgásmico asco que nos despierta, su ternura contaminada, espuria y maledicente, escalofriantemente atractiva, amor de fuego siniestro, el más oscuro y por consiguiente el más deseado de todos, al que nos resistimos sin saber cómo más fascinados.

Arbitrariamente engomados, embelesados toques de pesadilla, la felicidad de saberte el nombre en la rabia infinita de no poder recordarlo, decirlo solo por partes, siempre fragmentariamente, porque jamás terminarás de acordarte, recordándolo en cada frase, el nombre de quien te amó con más ferocidad y desapego, con la distracción más apasionada.

Deseándote con crueldad los mejores vientos, el despropósito y la ambivalencia más ardua, solo para corresponder la amargura que me depara recordarte en el olvido de cada nombre, su desvanecimiento impecable, amor de diosa olvidada, amándote con tu tierno, bello en extremo y siempre temible o confuso aborrecimiento.

2. Acuérdate de Invocarme. Este texto que a todas luces no escribí para ti, es el que mejor expresa lo que ahora somos, sin ser de nada el mínimo trazo, el insomnio también de 
fiebre y temida ausencia en que ya no me importa saber si estás o no estás desnuda, infortunio en el que descubro el encanto de una desfascinación sin desfallecimiento.

Cansándome a cada rato, un signo de otro en el que agoniza el sentido, pero que ni acaba de morirse ni de continuar sin poder morirse, remolino preñado de tensiones, pero eso sí, lastimosamente imprevisto, bien entorpecido de las vaguedades que siempre quise evitar contigo, el sinfín de las vaguedades para hablarte siempre tan claro.

Memoria desde el comienzo obsoleta, enunciación de una amargura de bordes sin importancia y perezosamente violados, como con desgano deshechos, violentados y distraídos al tiempo, virulencia inexpresiva y hosca, contundente a pesar de inconsistente, maleable y magnífica, rotunda para explicitar el conflicto que habitamos pero que ahora es intrascendente.

Superfluoy rico en matices, sobreabundante en nuevos matices de inanidades, memoria en flor machacada, desde antes obsoleta porque el pasado que evoca nació imbuido de una tristeza innegable, un brinco y salto de asombro al tiempo de ensombrecerse, mutilarse cuando el momento era otro, y ya perdido insiste en afantasmarse, mostrarse a pesar de la pesadumbre, exhibiendo una falta de temor asombrosa.

Ennoblecido de un despropósito así de fuerte, infatigable y sin timidez portentoso, de endurecido rostro, adusto en todas sus frases, a veces sencillo y edulcorado, este texto que sin duda escribí sin pensar que era para ti, poseído de una transparencia de ambigüedad tenebrosa, memoria despetalada, el imprecisable y justo artilugio de recordarte, constitutivamente incompleta, de tan fragmentaria irrisoria, ardida herida que no supura, ni se nota pero no es insensible.

Como sabes que ya no importa mentirnos, decirnos las falsedades que no supimos que no encubríamos, transformando la brillantez de un despropósito extraordinario en la terca y fácil rutina del olvido que ahora esquivamos, que nos elude diciéndolo, ya sin saber quién eres, extrañando una falta más radical de extrañeza, ahora que tu rostro es inatrapable, no por manida ausencia, el encanto de saber estarte perdiendo el rastro, disipándote y respirándote, acercándote a la mudez de una curvatura cerrada, mecida en un vértigo amorfo, pero cernido y transfigurado el motivo inaparente de estas palabras, si solo dejaras de estar dictándome, de abandonar estarme acosando.

Sin ser de nada el mínimo trazo, porque lo de perderte el rastro no lo sabía hasta que lo dije, hasta que recordé estarlo oyendo de tus labios, sin saber si no nos engañábamos ambos con eso de oírnos claro, olvidar que perdía el rastro encontrándolo, soñando encontrarlo, disminuyendo el tono hasta ignorar si oyes, pero matizando el resto sin ocultarlo, la verdad de lo que sentimos.

Recordar el influjo de un atardecer así, tu desnudez cualquiera, la desventura de seguir hablándote, la desvergüenza de invocarte después de todo lo que ha pasado, solo porque sabes que no es a ti a quien hablo, dirigiéndome con precisión innombrable a una voz indecisa, el contorno de una voz apagada e infatigable, certeza de que me hables más 
tarde, y como si fuera poco además te acuerdes de invocarme, llamarme indirectamente.

Sin ser de nada la mínima sombra, porque en otro rostro sabrás de mí lo que nunca te dije y me dices, por desperdiciar la oportunidad anhelada, la esperada imperdible coyuntura, niebla de imantación indecisa, la atracción que solo llegaba cuando ya el encanto se había perdido, por acordarnos ambos de olvidar hablarnos, ni tan simple que sea la cosa, la falta solo de un remitente, la improbabilidad tosca de que me entiendas, queriendo ver en la luna otra escena velada.

Impidiendo ver en la luna la redondez obvia que me observabas, tapando el cielo encubierto, sin verte las facciones turbadas, llamándote de otra forma, en otros nombres doblada, replegada y rabiosamente arrugada, porque sin recordar el placer exacto ya no interesa que oigas palabras, contraída y casi desfigurada, memoria demasiado ultrajada, estrujada con exceso, o aplazada sin cesar en interrupciones imperdonables, el discurso este que no iba dirigido a mí pero en el que me comunicaste lo esencial que ahora no somos, lo que no sentimos de una forma tan detallada, ni habíamos sentido antes de no poder acordarnos, recordarme tú con esas muecas rarísimas, interminablemente dictándome, memoria apenas rozada, la caricia equivocadamente entendida, un gesto engañoso de ternura impotente, innecesaria y además desencaminada.

Comprendida erróneamente, porque no era a mí a quien mirabas, ni podías ser tú el objeto de estas palabras, como dos extraños hablándonos, invocándonos pero a través de otros nombres, irreconocibles los nuevos rostros, inconcebibles e indirectamente los mismos, como si nos hubiéramos olvidado de todo, como si algo hiciera que nos olvidáramos de nosotros.

El irrepetible amor que no nos tuvimos pero del que siempre estamos hablando, el que nos habla a nosotros y que es lo único real en toda esta pesadilla, este amasijo de recordarnos, sin esperanza siempre acordarnos, será lo único y desgarradoramente cierto, el irrepetible amor que solo tuvimos, siendo los únicos en olvidar que sentimos con tal intensidad ese olvido, sabiendo que si no era a mí a nadie pudiste evocar esta maravilla, y viceversa pero añadiéndole algo, un rasgo de inventado asombro, que solo a través de ti olvidaba que estuve contigo.

Como si nada hubiera pasado entre ambos, como si la nada que pasó entre ambos estuviera de a poquito espesándose, condensándose, tímidamente insinuándose, empezando a recordar otra cosa, algo más que la desnudez simple de estar ausente, antes de recapitular olvidarnos, acordarnos despiadadamente de nada, repitiéndome tú que el insomnio no es de fiebre y temida angustia, o ausencia en flor machacada, pero menos mal que no estabas triste por causa mía ni nunca oíste el absurdo intenso de estas palabras, a mí que tu recuerdo ignoraba, vivificándome y extrañándome, desmembrándome en artimañas, desatándome una angustia insufrible, como la nada en que un mundo se arremolina, desinflamada memoria que no perdona, ni en esta ni en la mínima sombra, un trazo de nada sin serlo. 
3. Recordando mirarla. Porque si así se acordaba de ella, cómo sería volver a verla, como si fuera solo improbable, reaparecida indecisa y noble, la silueta de su finura entre líneas, cómo sería más tarde, de veras cómo sería más tarde, invisible no simplemente, imaginando las conexiones a esa forma de su nostalgia, de nubes esa nostalgia y de miedo por el paisaje entrevisto, acercándose a lograr verla, intuirla siquiera un poco, facciones todas indistinguibles.

Sin rasgos ni facciones que no sean todas indistinguibles, inolvidables e indistinguibles, desfigurada o figurativa, olvidando siempre su rostro, saber verla, acordarse de recordarla, mirarla en las imágenes justas, angustia de percibirla, secuela y cicatriz imborrable del vaticinio, recíproca ambigua de sus verdades, presencia ingrávida afantasmante, atrasada por un pellizco, el zarpazo divino en el rostro de su nostalgia, la organización inmemorial de otras formas de otros adioses, porque si así se mostraba ahora cómo sería cuando cogiera confianza.

Premeditado asalto de voz traviesa, jugueteando por un pequeño entredicho, la mínima sombra, el intersticio de su mini-mínima sombra, la mismísima estrafalaria, hasta que perdurara la estela negra, la circunspección ambigua de su estela negra, sin bordes ni mencionarlos, sus límites tornadizos, adversa ambigua en esas visiones, suerte disociativa en trance.

Deslumbrado de sombra y eco, o encandilado opaco por esplendores, conmemorando olvidarla, apaciblemente olvidarla, teñirle más fuerte en su desnudez los trazos que la tocaban, disociando la engreída precisión de su figura, difusa o desfigurada, deslocalizando nombrarla, hundirle en la inter-costilla el filo de sus visiones, amargura incierta y desenfrenada, indecisión de corola abierta, descubriendo el motivo enigmático en la enramada.

La predilección de absurdo en todos sus actos, diosita reaparecida, la nunca ida idea que la aureolaba, renovadamente imprecisa, fue la caricia de su sospecha menos que un mínimo viento, porque sería así como se vería más tarde, recordando acordarse, cansada en la danza de su nostalgia, pero anticipando del cielo nocturno un rugido de bestia inmensa, como si no fuera solo improbable el acceso a las fuentes iconográficas, desfigurada y figurativa, o descompuesta amorfa en figuraciones.

Desesperando por verla, la misma en fulguraciones, acordarse de estarlas viendo, siluetas de formas huecas, conmocionadas con esperanza, la corona de meridianos fulgores en que esperaba alegrarse, transformándose sin quererlo, tímidamente anunciándose, presentándose en esa forma, olvidando que eso era presentarse, acordarse de recordarla, porque así sería como se vería más tarde, estar presente de alguna forma, sensibilizarse a su invisibilidad solo a medias latente.

Recordando estarla mirando, tan de cerca estarla mirando, esforzándose por ver algo, su rostro o lo que sea de ella, haciendo el máximo esfuerzo, así sea la mínima 
sombra, un atisbo siquiera, el más pequeño vislumbre, una minúscula manifestación al menos, con toda su alma empeñándose, exigiendo completamente su capacidad de visión, para verla o intuir que podía verla.

Pero, ¿para ver qué?, diría que para verla mejor, pero ¿para ver mejor qué?, con más detalle sin saber lo que era un detalle, o si cabían detalles en esa imagen, con mayor precisión la ausencia de criterios para determinar la precisión de esa imagen, fractalmente pintada, visión de corola abierta, de par en par esos labios, ofrecidos grotescamente, obtusa y tímidamente insinuados, angustia de percibir la misma mirada despetalada, invisible no simplemente, impúdica y desgarrada, recatada con esmero, absolutamente entregada a la lascivia de su mirada.

Cada vez más cerca, cada vez más cerca o con más nitidez cuando no estaba claro cuándo estaba más claro, o si era más nítido el borde de la nube que dibujaba, cada vez más cerca, temblor adentro del vaticinio, prostituida lujuria de examinarla, humo dentro del humo hasta el vértigo, sin saber lo que estaba viendo, recordando que debía saber lo que estaba viendo, mirando inconscientemente, presintiendo mirarla, imperceptiblemente apreciarla, desfigurada precisamente en la exactitud de tantos manchones.

Y todo ¿para ver qué?, morirse para ver ¿a quién?, la memoria que se esforzaba, acordándose solo del acto de recordarla, solo de eso, solo de eso sin saber eso, de angustia absorta o de percibirla, de seguir con la ausencia de ojos la astucia de imaginarla, acordarse de estarla viendo, la obviedad de una frase así, únicamente larvaria y boba, desesperadamente boba ausencia de forma en el intervalo en que la miraba, el mínimo intervalo en que se veía que no veía, porque si así era ahora que estaba ya imaginaba cómo sería cuando se fuera, siendo delicadamente visible del lado de una membrana entre transparente y torpe, de una sola pieza el bloque difuminado que la observaba, atontadísimo, deslumbrado idiotamente por ella, obnubilado por el juego inacabable de sus memorias, impresionado por sus contornos fugaces, estando así solo asomada en los límites, delicada y casi solita, solícita en la enramada, silueta de formas huecas o exasperantes, definidas en un cosquilleo sublime.

La fugacidad de un reborde impreciso, recordando que ver era eso, o que algo así podía simplemente mirarse, ojearse sin peligro, abismarse en la falta de esa mirada, presintiendo ya lo insensible, el estado inerte de roca y nube en que tornaría sus perversiones, constataciones, ilusiones de trastornado nombre, porque si así era ausente cómo sería si de verdad le faltara, acordándose recordarla, fijar en contornos las manchas ultra-próximas en que se ahogaba, el contorno de manchas que aneblinaban la arrogante precisión de sus fraseos, ahogo más triste en estos fraseos, renovación de ese sinsentido en fraseos, porque si así eran sus descripciones cómo sería cuando en serio viera de lo que hablaba.

Mirando de frente el axioma tentacular de sus ojos, suspirando acordarse, silueta de diosa adversa, emborronamiento del momento justo, presentimiento de temible 
rostro, paisajes de olores ambos, poli-sintiendo que era ridículo querer expresar esa forma, su figura en lo inaparente, inobservable mirarla, acordarse siempre de recordarla, verla así, suspirar decirla, de estas frases un pellizquito siquiera, el mínimo pellizquito que siguiera y lo acosara dudando, porque si eso era estar presente cómo sería cuando de veras faltara.

Siluetas que recordaba danzantes, y ya vería cuando cogiera confianza, inoperancia tranquila y léxica, prontitud para detestar sus palabras, frente a la criatura de carnosos pétalos en que intentaba recordar que miraba, conmemorando olvidarla, apaciblemente olvidarla, circunscribiéndole su impaciencia, desnuda de ella, abandonada de sí en sus contornos, el desdoblamiento identitario en un matiz refractario al espejo, un doblez esplendente, reacio a percibir que olvidaba, en sus límites pataleando, olvidando que esas eran presencias.

Callando ausentarse, mostrarse sin esplendores en curvas policromadas, a pesar de la destreza impotentes, tramando un secreto de proporciones escalofriantes, anticipando del cielo nocturno un rugido de bestia inmensa, acordarse de recordarla, angustiosamente recordando que se acordaba, recordando y olvidando lo mismo que se acordaba, insensible aurora desparramada.

Entregada a la veleidad de los espectros que la componen, cuya presencia es inubicable ubicua y estrafalaria, preciso ahí, la deformación perspectiva que era, diosa de forma adversa, empeñada en el color de sus fonemas, la tranquilidad quebrada de su memoria, la doble engañifa de sus palabras, porque si eso era precisarlas cómo sería cuando en serio quiera nombrarlas, superando por lo siniestro la tendencia a casi asustarse, casi con frecuencia acordarse, casi pero no solamente invisible, acordarse de recordarla.

Ausentarse de su mirada, porque no fueron ni ensoñaciones ni parecidos, y cómo sería si fueran, acercándose a ser del nombre un temblor de sombra obsoleta, rasgos de una preocupación creciente y disociativa, recientemente resuelta, encontrada abstracta, simulada en ciernes, premonitoria de otras imágenes, quebrada en punta a quejarse, responderle a las enseñanzas que la habían difuminado, configurándole la mirada, atontándola sin remedio, a ella diosita reaparecida, o diosa de apariciones inobservables.

Invisible no simplemente, en visiones de transparencias y oscilantes nuevas opacidades, pulsando acordes sensibles, pero por lo siniestros - de asombro-casi como su rostro borrado, tenue o desdibujado, solo preciso desdibujado, porque si así era adorarla ya sospechaba cómo sería cuando ya ni verla quisiera, ni en pintura ni nada, necesitando olvidarla, conmemorarla en nuevos tachones.

Borrones de nubes huecas, espectros desalentados, soplos en cielo de anticiparse, reclinarse con el respeto que le merece la aurora, recordar que la estaba viendo, que esa era la imposibilidad de estarla siempre mirando, a ella la intransigente desesperada, la imperceptible, la Madre amorfa de sus visiones, cuadrada en frases reptantes, desfigurada y figurativa, acechando mirarla, persiguiendo un recuerdo brumoso, majestuoso inaudito. 
Palpado invisiblemente o solo intangiblemente visto, cuerpo desnudo sin esplendores, desnudez de todo contorno, iridiscente de puro ensueño, la espectral anatomía que sin tregua lo fascinaba, afanándose más por verla, pero ¿qué era lo que observaba?, en últimas ¿qué era lo que tanto observaba?, ¿qué demonios miraba?, anhelando infinitamente acordarse, poder verla, más de cerca mirarla, apreciarla en todo detalle, su rostro o su encajonadura de sombra, el misterio que la esquivaba, hurtándose en esos ojos, haciendo un esfuerzo mayúsculo, ardid de intento inflexible, el mayor empeño para detallarla completa, su cuerpo de irisaciones, desnudez de todo contorno, vaporizada anatomía del delirio, no simplemente invisible.

Hasta el mínimo ensombrecido detalle, ignorando lo que buscaba, desconociendo el límite al precisarlo, los contornos disipativos de ese agujero extasiado, un par de ojos quemándose en la falta agónica de su objeto, binocular monomanía escópica sin medida, unidireccional y ondulante, la hendedura en que se abismaba, sin esperanza de recordarla, acordarse de no poder acordarse, ni verla hasta ese sin fondo, la angustia ultra - próxima en que se hallaba.

La agonizante incompletud ya terminada que la miraba, a ella en la simulación de su perspectiva, ella que era la simulación de su perspectiva, ilusión óptica irremplazable, desplazada en un parpadeo, reubicándose cada vez, escurriéndose recordarla, amplificadamente reduciéndola a simple y pasiva observadora, contemplándola casualmente, percibiendo en el cielo nocturno un rugido de bestia inmensa, de testigo ocular a insidia de miopía afectada, infección evidente del aparato sensible, conjuntivitis desenfrenada irritante, por la retina o el iris, midriasis de corola abierta, invisible no simplemente, óptica difractante y tosca, desgranada en lentes fugaces, superpuestos y asociativos.

Enfoque de alta y tonta resolución, de altísima y tonta resolución afectada, de afinación multiplicativa o tierna, preciso en el cosquilleo de su memoria, fina en el reflejo que la apreciaba, sin orilla en luna espejeante, porque si no sabía que recordaba cómo sería si estuviera mirando, presenciando olvidarla, patentemente olvidarla, ante sus ojos y por su ceguera perdiendo toda presencia, borrando la insensatez de la huella, ciegamente apreciando su pérdida de presencia, el exceso de su pérdida de presencia, desconfigurándose apareciendo frente a sus ojos.

Evidentemente recordando olvidarla, porque si no llegaba a saber de qué se estaba acordando, entonces ¿cómo iba a pretender después olvidarla?, ¿cómo podría hacer eso?, acordarse de recordarla o apremiarse para olvidarla, ¿cómo recordar eso?, ¿semejante antinomia y absurdo?, ¿semejante inolvidable antinomia?, ipretender tamaño exabrupto!, ¡ a todas luces una bobada, una insania de bulto!, ¡tal tontería de sumo absurdo!, jun sinsentido de ese calibre!, cuando salta a la vista la incongruencia mayor de sus frases, ¿cómo intuir acordarse de eso?, ¿cómo siquiera acercarse a acordarse un poco de eso?, primero olvidarla o primero acordarse de ella, o primero ignorar lo que era primero, observando la pérdida de cualquier residuo de presencia, 
el mínimo que ignorara, y muriéndose por verla, desviviéndose para llegar a verla siquiera, un poco al menos, muriéndose por contemplar ¿qué?, ¿qué cosa?, ¿a quién en particular?, desesperando abarcar ¿qué?

Dejarse traspasar por ¿cuál mirada?, por ¿cuál de las más terribles- devoradoras o petrificantes de las miradas?, fragilidad de no recordar verla, fragilidad extenuada de no poder dejar de mirarla, desesperadamente boba, desesperadamente danzante y boba, sublime en su mínima tontería, volviendo a mentir verla, olvidar que siempre la estaba viendo, que solo podía mirarla o mentir que podía mirarla, olvidando siempre su rostro, mirando de frente su ausencia, no simplemente invisible, en siluetas de ojos adversos, alrededor de la falta de ella, el quiebre en que lo miraba, pero también a ella la imperceptible, la intemerata, la Madre amorfa de sus visiones, desmintiendo mejor que así era que la había visto, paisaje de otra memoria, engañando estarla mirando en un paisaje de otra memoria, ni en pintura ni nada, menos simplemente visible, mucho menos que simplemente visible, conmemorando olvidarla, apaciblemente y sin figura olvidarla.

Post scríptum despetalado: antes de ti en la angustia de ti, el duelo que ahora siento no lo siento por haberte perdido, a ti que nunca estuviste, el duelo es constitutivo de mí, no lloro por no poseerte más porque de todas formas nunca te poseí en absoluto, desde siempre no te tuve, es la ilusión de haberte tenido la que al romperse me causa este dolor, porque ambos sabemos que ni aun estando juntos estuvimos realmente juntos, esto que ahora me ahoga es lo que siempre me había ahogado, antes de ti en la añoranza de ti, en la inagotable nostalgia de ti, pero también porque nunca te has ido, yéndote siempre nunca te has ido del todo, fractal y poderosa agonía, cuando pensaba que eras mía por supuesto que no lo eras, estando o no estando juntos, "preciosa joya en los talismanes", antes de ti en la angustia infinita de ti, tú que eres la angustia y la negación de cualquier angustia. 


\section{Epílogo: Zaratustra Zombie}

\section{EXTRACTOS DEL DIARIO DE ELABORACIÓN/ FINALIZACIÓN DE LA TESIS}

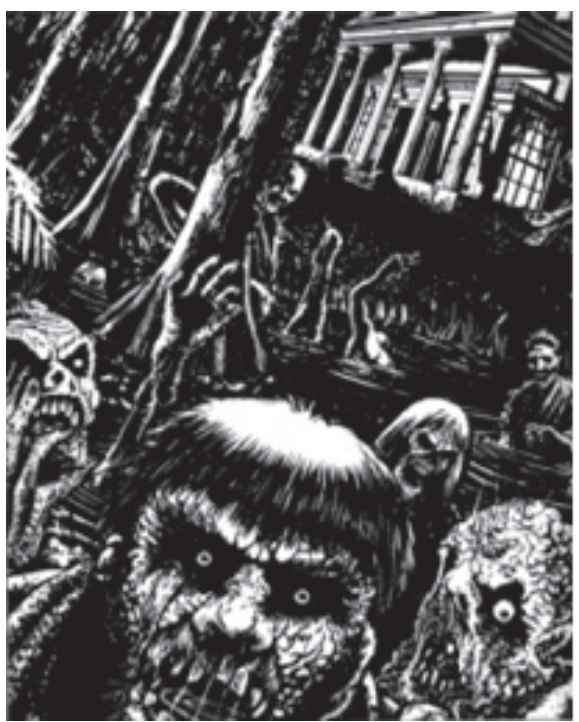

Darkkos Manse, James Fletcher, Comic art now, (2009, p. 92).

10.05.12. Acabo de ver en la Lerner un libro titulado Filosofía zombi; lo abrí al azar y encontré una referencia a Nietzsche, extraña coincidencia, justo esta semana que estaba repasando lo del tema de la vida y la muerte en la escritura de la historia.

12.05.12. Finalmente, adquirí el libro, no lo pude abandonar hasta que prácticamente lo había concluido, imágenes de Zaratustra hormigueaban mientras lo leía, ¿qué hado me puso en las manos el texto? 
13.05.12. Hoy, mientras visitaba a mi hermana, noté que mi sobrino de ocho años veía un cómic, resultó ser Marvel Zombie Cómics. La estética del dibujo me impresionó muchísimo; hace mucho tiempo que no leía historietas, debo dejar de distraerme con material impertinente para el desarrollo de la tesis.

17.05.12. ¿Por qué ocuparse en una tesis de doctorado de la cuestión zombi?, ¿En qué medida resulta una metáfora valiosa para ensayar un "epílogo" o algo semejante?, ¿Por qué rescatar a estos asquerosos seres ahora? "El zombi es un problema de escritura, como ya hemos dicho, con el que infectar cualquiera de los signos que componen nuestros sistemas culturales y, desde allí, volver a pensarlos nuevamente" (Fernandez, 2011, p. 197).

04.06.12. Definitivamente creo que los "últimos hombres" descritos y escarnecidos en el prólogo de Zaratustra (Nietzsche, 2006, pp. 40-42) son zombis.

05.06.12. "La tierra se ha vuelto pequeña entonces, y sobre ella da saltos el último hombre, que todo lo empequeñece. Su estirpe es indestructible, como el pulgón; el último hombre es el que más tiempo vive" (Nietzsche, 2006, p. 41), esta cita acerca del "último hombre" en el Zaratustra me transmite un escalofrío grotesco, imagino la zurumbática vida de esos seres descerebrados, que todo lo empequeñecen y pudren, su asimilación al "pulgón" como plaga es significativa, y ese vivir mucho tiempo es una especie de muerte en vida, entregados a la miseria de sus comodidades y costumbres debilitantes.

06.07.12. En el tono del libro Filosofía Zombi (Fernández Gonzalo, 2011), esta sería una sección de "escenas borradas" o "suprimidas" de la tesis, de ese texto me atrapó su organización cinematográfica: en vez de introducción dice tráiler, los capítulos se dividen en "pistas", y al final como en todo DVD hallamos "material adicional" que, por supuesto, incluye las mencionadas escenas borradas. Todas las referencias (bibliografía, etc.) se hallan agrupadas bajo el nombre "Créditos". Sin embargo, no es el libro como tal lo que me ha impresionado tanto, es otra cosa, es algo dicho a través de él, como si en el momento de la transmutación alquímica algo hubiera salido mal y el sujeto quedara convertido en una piltrafa amorfa, como en la película La mosca de David Cronenberg (20th Century Fox, 1986), el que experimenta comete un error y se empieza a metamorfosear de la forma más odiosa e indescriptible, una especie de fase zombi del opus alquímico, un momento de nigredo y putrefacción, anímica y mental a un tiempo.

12.07.12. Noto algo raro en el desarrollo de la tesis, la preocupación por incluir referencias al quehacer del historiador me hallevado cada vez más a pensar en los moldes de cronologización que subyacen a su tarea, a las elecciones pre-conscientes que guían su trabajo, como decía Hayden White, pero, ¿realmente lo guían o lo desencaminan?, ¿de dónde extraen su fuerza compulsiva esas representaciones del pasado?, ¿cuál es el poder de fascinación de tal imagen del tiempo?, a veces me siento tentado a escribir sobre la temporalidad de una escritura parasitada irremediablemente por un coeficiente 
de mutación extraño, ex machina, entre sueños y otros pasajes rarísimos del Zaratustra que se van haciendo más nítidos, coagulando de manera borrosa, el impulso es siempre discontinuo, como he tratado de hacer - sin saber con qué fortuna- en los excursos, algo tiembla de modo incontrolable en esos ritornelos textuales.

15.07.12. Permanentemente pienso en el personaje de EL HORLA de Guy de Maupassant, el cual, como en cualquier aventura de Lovecraft, se halla inmerso en unas elucubraciones de tal intensidad que acaban por desbordarlo, cree ser perseguido por un ser invisible que se alimenta de su energía vital, pienso en el tiempo que toma ese acecho, me siento inspirado y asustado por esa hipótesis, estos días he retocado mucho el $3^{\circ}$ capítulo sobre parásitos mentales y voces internas, se me ocurren ideas delirantes.

07.08.12. Tengo completamente clara la imagen de "Zaratusta Zombi" (en adelante $\mathrm{ZZ}$ ).Tomó tiempo que germinara en mí. Es un motivo y un ritornelo exultante, un símil y un eje deimantación temática.ZZ. DelaZ alaZ el intervalo es imperceptibley definitivo, como de Zaratustra a los Zombis o viceversa, ese tránsito reversible corresponde quizá a la rara temporalidad del remake, de las variaciones sin fin ni comienzo, de la $\mathrm{Z}$ a la $\mathrm{Z}$ experimentamos un flujo de modulaciones antes que la transición de la causa a su efecto o del génesis al apocalipsis, como sostiene Jorge Fernández Gonzalo en Filosofía $z o m b i$, texto zombi en sí mismo y en el que no se escatima nada a la apuesta postconceptual por una filosofía zombi, ZZ no nos sitúa en el arco cosmológico del alfa al omega, ni en la indexación crono-alfabética o jerárquicamente ordenada de una guía A-Z, nada de eso, penetro en ese intervalo a través de esta delirante cita (extraída de la sección titulada "escenas eliminadas" del libro Filosofía zombi):

Nietzsche y los muertos vivientes. En la cutre película Zombie Strippers (2008) hay al menos un par de cosas reseñables. Una de ellas es el curioso inicio con su crítica al modelo político americano y a sus baremos electorales del futuro: George Bush sale elegido por cuarta vez, junto con el vicepresidente Arnold Schwarze... Terminator, para que nos entendamos. A continuación se enumeran las diferentes guerras en las que el gobierno yankee anda atareado. El segundo suceso que reclama nuestra atención son las atentas lecturas a lo largo del metraje de la actriz porno Jenna Jameson de la obra de Nietzsche (?). Ironía, sarcasmo. Vaya usted a saber. Aunque no acaba ahí la cosa. La stripper dedica sus descansos a echar una ojeada a las obras del pensador alemán, pero, una vez que ha sido infectada y se convierte en zombi, la cosa cambia: ¡Nietzsche se ha convertido en un libro de humor! Una desfigurada Jenna Jameson se ríe a pierna suelta con la lectura del filósofo. Por si alguien pensaba que no podía deconstruirse a Nietzsche. (Fernández, 2011, p. 203).

$\mathrm{ZZ}$ es ese intervalo entre la primera lectura de Nietzsche (que imaginamos filosóficamente seria, eso sí, desde la mirada de una actriz porno) y la segunda (ya contagiada por el virus zombi).

08.08.12. Todo el día he pensado en la risa ex-porno de la actriz zombi, me hace sonreír y me aterra, no solo por todos los pasajes en que explícitamente Nietzsche habla 
de la risa, sobre todo la risa del pastor que ha escupido la cabeza de la serpiente negra al final De la visión y del enigma, incluyendo el epígrafe al Caso Wagner en que se referencia a Horacio para decir que se puede decir la verdad con una carcajada, insinuando que se puede ser muy serio y a la vez jovial, como al inicio de Aurora se celebra esa dinámica entre lo espantoso y el buen humor, allí donde se conmina a mantener la jovialidad aún en asuntos apesadumbrantes o tétricos como los que ocupan la mente de Nietzsche también en el prólogo al Anticristo. Lo que se genera es la risa como efecto, la risa del super-hombre quizá, o la risa que mató a los dioses cuando uno de ellos proclamó "solo hay un Dios", las obras de un Nietzsche humorista...

12.08.12. ZZ es la repetición de la diferencia, la auto-replicación del virus, de la idea como pegajoso Meme, me parece extraña la relación entre Genes y Memes, adquiero el libro de Kate Distin El meme egoísta (Distin, 2005), su título es un remake de El gen egoísta, publicado a finales de los setenta por Richard Dawkins. La comparación entre genes y memes como unidades de auto-replicación tiene una fuerza enorme, los memes serían genes inmateriales, informáticos. No dejo de asociar la moral con un sistema de memes, la obsesión de Nietzsche por la transubstanciación de las tablas morales, en el entorno autoinmunitario de la teoría de sistemas se podría hablar del capitalismo y su concepción del tiempo como una plaga memética, recuerdo la película El Origen con Leonardo di Caprio (Inception, dirigida por Cristopher Nolan, Warner Bros. Pictures, 2010), en la que se detalla el espionaje onírico entre personas, para acabar aludiendo a la inception o inoculación de una idea en el subconsciente de alguien, ¿de qué manera aparecen y cómo se vehiculan las ideas contenidas y desbordadas en Así habló Zaratustra de Nietzsche?, ¿qué avatares determinan su proliferación?

14.08.12. Creo haber decantado algo clave para la tesis, se trata de la relación entre Genes y Memes. Es importante destacar que la idea original de Dawkins en El gen egoísta era reducir o considerar a los seres humanos, y en general a los seres vivos, como medio de propagación de los genes, como vehículos solamente, ¿en el caso de los memes ocurriría algo similar?, ¿ nuestras mentes no serían sino el entorno para su proliferación, para su multiplicación, para su reproducción exponencial?

15.08.12. Debo tener cuidado, empiezo a dormir cada vez menos. Me asalta la idea del tiempo zombi como virus, como la plaga que allí se vehicula, tiempo sonámbulo, atrapado en el intersticio de los mundos, asíla imposibilidad de morir del zombi, como esos remakes que definen el género $Z$ como parte de un mercado cinematográfico plagado de refritos, así presiono $\mathrm{Ctrl}+\mathrm{Z}$ para deshacer el error mientras escribo (en otros programas la opción "deshacer" funciona también presionando las mismas teclas), pero el error no queda deshecho, no desaparece simplemente, ese Ctrl+Z muestra la iterabilidad e insustancialidad de la estética zombi, su efecto de rebote temporal. La primera película de zombis que vi se llamaba El retorno de los muertos vivientes [dir. Dan O’Bannon, Orion Pictures, 1985], creí que era algo así como la segunda parte de otra película quizá titulada solo Los muertos vivientes. Pero no era así, he investigado y descubierto que la primera película ya es un retorno [una 
adaptación cinematográfica de la novela "The return of the living dead", escrita en 1977 por John Russo, que a su vez es un remake esta vez del cine hacia la literatura de uno de los guionistas del film pionero (1968) "The night of the living dead" del legendario George A. Romero], esa es la paradoja del zombi, deshace el privilegio del original (humano) sobre la copia (zombi), en el principio era el zombi, por supuesto que en el principio era el zombi, un principio siempre en retardo respecto a nuestros marcos clasificatorios y causales, de allí que el género $\mathrm{Z}$ solo pueda definirse a partir del remake, obliterando la idea de una fuente primera y luego sí las inmundas e impuras copias, nada de eso, con el zombi el contagio es originario y derivado a la vez, drama de una escritura parasitaria como escritura zombi también.

17.08.12. De tanto cortar y pegar, escribir y re-escribir se generan rarezas significativas en la tesis, sincronías extrañas, decido aumentar algunos capítulos, borrar otros pedazos, queda el estatuto de una ficción narrativa que mezcla fragmentos expresivos de las fuentes más heterogéneas, articulando órdenes discursivos y no discursivos de lo más variopintos, así las cosas, pienso (no sé si infecciosamente) en la idea de un Zaratustra Zombi entendido a partir de las mutaciones que ha sufrido en la cultura popular, pensando en eso y justo me encuentro esta afirmación del artista Michael Betancourt (como colofón a la introducción del propicio "Homo Sampler"): "las diferencias y dinámicas que contraponen el mundo del arte a los mass media son tan importantes, y tan parecidas en su dominación, que cualquier forma artística de ruptura deberá, necesaria e inevitablemente, abordar ambas formas culturales a la vez" (Fernández Porta, 2010, p. 25). Zizek dice en Mirando al sesgo que ese procedimiento ya lo había ensayado Hegel, lo cierto es que la idea de vincular el arte y el pop comercial, la filosofía y los zombis, el arte y la crítica cultural, el cómic y la historiografía va ganando fuerza en mí.

Me viene a la cabeza la imagen misma de Zaratustra, a Nietzsche ésta literalmente lo "asaltó" en un arrebato que él no dudó en calificar de éxtatico. Hay un poema que narra ese desdoblamiento súbito (epígrafe y motivo del segundo excurso, titulado "La hora de aparecer"), como si su cerebro hubiera sido parasitado de forma fulminante e irreversible. Igual Nietzsche recicló esa imagen de la religión zoroástrica persa del Zend Avesta, y quién sabe qué otras anteriores mutaciones había sufrido esa idea (encarnada en el personaje). Me empieza a interesa mucho analizar a Zaratustra intersecando sus derivas nobles en la obra de Derrida o Deleuze, pero de forma compulsiva cada vez más siento la necesidad de hablar también desde otros

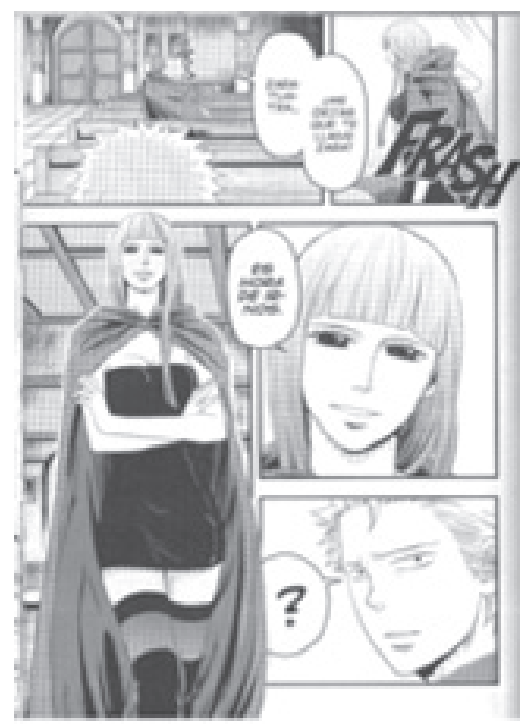

Fuente: Nietzsche (2011). 
referentes (menos academizados o intelectuales), como quería Zizek en Mirando al sesgo, es decir Zaratustra Zombi como un objeto cultural de contornos indefinidos, seudopódicos, en variación constante. Desde este ángulo haría mal en considerar al prístino Zaratustra por oposición a sus malas copias o lecturas, acorralado por estas intuiciones me encuentro el manga Así habló Zaratustra.

Hallado por azar en la librería del Fondo de Cultura Económica. en La Candelaria, mi primera reacción fue de absoluto rechazo, ¿cómo era posible la "degradación" de una obra mayor de la poética y la filosofía de todos los tiempos?, ¿qué desatino y absoluta falta de respeto había llevado a los japoneses (su título original es Zaratustra kaku katariki) a semejante exabrupto?, para colmo de males leí en la contracarátula:

No sabemos que pensaría Friedrich Nietzsche si viera el título de su obra Así habló

Zaratustra impreso en la portada de un manga. Lo que sí sabemos es que son muchos los jóvenes que leen cómics y pocos los que se atreven con un libro de filosofía

Y para rematar este emblema digno de la mercadotecnia de la industria editorial más barata:

La magia del cómic en una historia inspirada en el pensamiento de Nietzsche. Lo mejor de la filosofía y del manga, por fin juntos.

Como un eslogan los bárbaros de la editorial Herder, pensé, mezclaban sin más ni más uno de los productos más comerciales como el manga (anime japonés) con la grandeza sublime del opus magna de Nietzsche, con desprecio rechacé (muy sintomáticamente) el librito manga de Nietzsche, pero esta actitud no me duró mucho, progresivamente me interesé por los mecanismos de traducción de los argumentos de Nietzsche al manga, de la curiosidad pasé al estupor al encontrar al personaje Salomé, una chica que encarna la idea de eterno retorno, de acuerdo a la lógica bastante dudosa y "masticada" del cómic.

La historia, a pesar del título, no tiene mucho que ver con el Zaratustra "original", se cuentan las peripecias de un niño llamado Zaratustra, un huérfano, se intersecan expresiones como "super-hombre" o "eterno retorno" bastante fuera de contexto, pero, ¿cuál es el resultado de este pastiche inmundo?, ¿este atrevimiento de la cultura popular sobre el clásico?, ¿valdría la pena, pensaba, dedicarle algo de atención al pasquín?, más por tomar el pelo y ya empezando a anticipar cómo podría sacar provecho de este anti-hallazgo desde al punto de vista de los zombis, decidí abordar las mutaciones que la figura de Zaratustra ha tenido en la cultura popular, en tal sentido me puse a escuchar el audio-libro en el que la voz del conocido actor colombiano Pedro Montoya (recordado en su papel de Simón Bolívar) lee con un tono afectadísimo ciertos pasajes. También vi un libro titulado Zaratustra un dios que sabe bailar del super best-seller Osho, indudable adalid de la literatura de autosuperación y gurú de la espiritualidad new age. 
En este maremágnum reflexioné que el caso del manga era diferente, su circulación masiva para jóvenes lo torna atractivo para el análisis, el personaje Salomé como voluptuosa fémina no deja de ser sintomático también, al igual que el intento de escenificar el eterno retorno haciendo coincidir al final del cómic dos Zaratustras de diferentes edades, me acuerdo de "Borges y yo", el cuento de Borges incluido en El libro de arena, pero también las cuidadosas referencias que hice en el quinto capítulo de la tesis al libro The death of Nietzsche's Zaratustra, en el que entre otras cosas se sostenía cómo el Zaratustra en su estructura narrativa presentaba y no solo aludía de manera conceptual al eterno retorno. Investigar sobre la estética manga. Buscar conexiones y afluencias desde la expresividad del cómic, las historietas y las novelas gráficas para abordar discusiones de filosofía y de filosofía de la historia en particular.

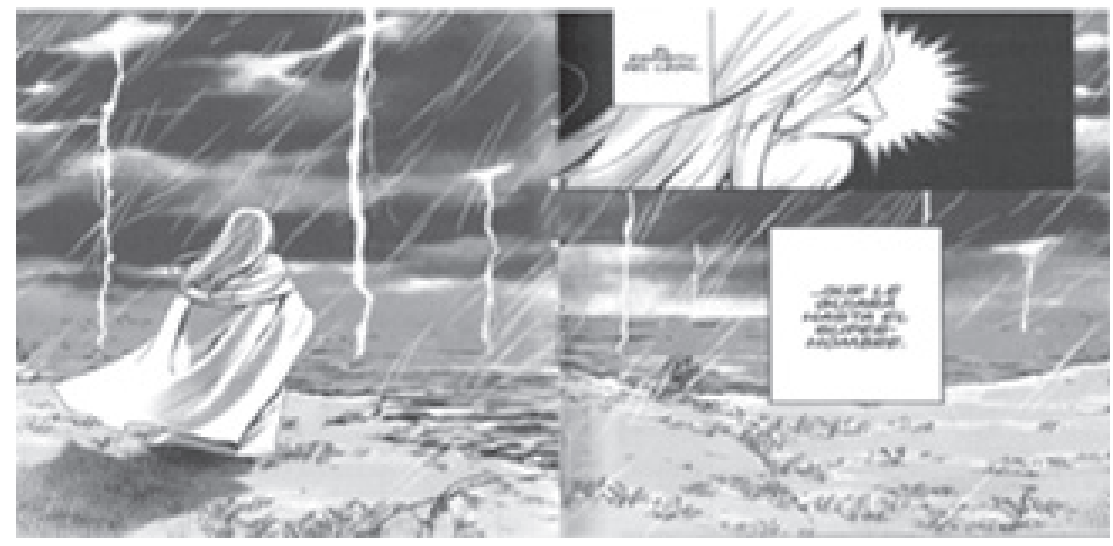

Fuente: Nietzsche (2011, pp. 16-17).

19.08.12. Me quedó sonando un fragmento del discurso del Adivino en el apartado del mismo nombre en Así habló Zaratustra, en la edición de Alianza dice así: "en verdad, estamos demasiado cansados incluso para morir; ahora continuamos estando en vela y sobrevivimos en cámaras sepulcrales!" (Nietzsche, 2006, p. 203), asocio esa vida sepulcral al merodear de los zombis y al tipo de vida sin consciencia $a^{90}$ que lleva el "último hombre" del que se burlaba en el prólogo. En junio había estado pensando en esa conexión, pero ahora la imagen de una muerte en vida es más nítida, en ese mismo capítulo luego de escuchar al desesperanzado adivino, Zaratustra cae en un profundo sueño, la descripción de este es todavía más increíble: "yo había renunciado a toda vida, así soñaba". En un vigilante nocturno y en un guardián de tumbas me había convertido yo allá arriba en el solitario castillo montañoso de la muerte" (Ibídem), ¿en el solitario castillo montañoso de la muerte?, ¿qué clase de sitio es ese?, cuál topografía espectral es la que aquí se evoca, la atmósfera parece sacada de un relato gótico o de un cuento de Edgar Allan Poe : "Una claridad de medianoche me rodeaba constantemente, una soledad se había

90 Es decir, sin consciencia del super-hombre, de las infinitas posibilidades de la voluntad de poder. 
acurrucado junto a ella; y, como tercera cosa, un mortal silencio lleno de resuellos, el peor de mis amigos", el sueño se va haciendo cada vez más ominoso, "entonces un viento rugiente abrió con violencia sus hojas y entre agudos silbidos y chirridos arrojó hacia mí un negro ataúd”.

Luego, nos enteramos de que "el ataúd se hizo pedazos y escupió miles de carcajadas diferentes", esa ruptura hace que broten unos seres híbridos que doblegan de pánico espanto al valeroso Zaratustra, siendo clave que de un ataúd broten seres con vida. Lo que me da vueltas y vueltas son dos cosas, la interpretación de este espanto por parte de uno de sus discípulos, aludiendo al poder de airear la putrefacción de ese castillo de la muerte. No se me olvida nunca el epíteto de Nietzsche como "abogado de la vida", sin embargo, se me aparece su imagen decaída, enfermiza, casi como un avatar deambulatorio y zombi, inflamado de vida hasta el vértigo, pero confinado a un cuerpo maltrecho y siempre adolorido. La segunda cosa es la descripción del tiempo en la "mansión de la muerte": "Así se me iba y se me escapaba el tiempo, si es que tiempo había todavía: ¡qué sé yo de ello!", es esa incertidumbre temporal la que ligada al aura mortuoria se ha vuelto un leitmotiv para mí, esa escena en particular, con su despliegue de imaginería siniestra me envuelve y me doblega también.

Me parece que las críticas de Zaratustra apuntan a salir de ese estado intermedio entre la muerte y la vida, como cuando dice que a aquellos que no se atreven ni a vivir ni a morir debemos precipitarlos mejor al abismo, muchas diatribas de Zaratustra caracterizan ese estado propiamente zombi en el que se hallan encerrados los hombres de su tiempo. Para ello hace uso del símil onírico "castillo de la muerte", no sé, puede ser una ruta de emparentamiento entre varios presentimientos.

02.09.12. Me acabo de despertar con una sensación difusa ya no acerca de los hombres que Zaratustra denuncia como zombis, sino acerca de Zaratustra mismo como zombi, recuerdo la discusión que en el libro de Paul Loeb The death of Nietzsche's Zarathustra se hace respecto a que Zaratustra muere al final de la tercera parte del libro y lo que se narra en la siguiente - la cuarta - ha ocurrido antes; según esa perspectiva el estatuto ontológico de Zaratustra es la de un no-muerto, ya fallecido en el exultante y extático canto de los "siete sellos" pero redivivo y zombi en los acontecimientos que siguen, o como si los eventos de la última parte con los hombres superiores hasta la llegada del signo fueran un flash back o incluso, como se diría cinematográficamente una precuela de las tres primeras partes, ¿por qué no puedo deshacerme de estas imágenes y concentrarme en otros aspectos de la tesis?

03.09.12. Los zombis se caracterizan por una pulsión no-muerta que Zizek no duda en emparentar con la "pulsión de repetición" de Freud, no solo una suerte de tánatos librado a sí mismo, sino una forma ni muerta ni viva de desborde libidinal del sujeto. ZZ, Zaratustra Zombi, también exhibiría esa voluntad de poder que extralimita los marcos morales usuales, mostrando así un apetito 
descontrolado y omnipotente, quizá no tanto hacia los cerebros o los cuerpos de sus víctimas, pero sí hacia formas de configuración de la voluntad de poder insospechadas hasta ahora.

07.09.12. Renuncio a combatir el evidente contagio mental que padezco por cuenta de esta "zombilosofía de la historia", siento que baja un poco la angustia de estar divagando en temáticas sin sentido, insustancialidades que por eso mismo no dejan de estar presentes, como el protagonista del Zahir de Borges, es la aparente nimiedad del objeto lo que hace que devore totalmente la atención y los procesos síquicos de quien lo mira. La tríada Zahir-Zaratustra-Zombi me sigue arrebatando las horas de sueño. Sin embargo, cuando decido bajar la guardia ante la evidente hipnosis o fijación o monomanía "muerto-viviente" que tengo y de cierta manera "gozo mi síntoma", como recomendaba Zizek, algunas cosas quedan en claro, solo entonces se me ocurre que la temporalidad que propone el zombi es la de un presente pesadillescamente repetido, como en un horroroso, espectral y purulento eterno retorno de lo mismo, estos seres se instalan en la imposibilidad de morir y de vivir, habitan ese intervalo monstruoso, nos persiguen desde ese vacío.

09.09.12. ¿Desde dónde nos mira el Zombi?, como motivo y como contagio.

11.09.12. Después de un intenso dolor de cabeza un relampagueo me pone a decir algo sobre una cierta "historiografía zombi". Me siento asediado por la imagen de los zombis y sé que se trata de algo infantil y bobo, impertinente como el retorno de un "real" reprimido, recuerdo haber leído que para Lacan lo real del cuerpo correspondía a esa imagen sanguinolenta y viscosa tan similar a la de la plaga de muertos-vivos, quizá se trata de eso, Zizek también habla de una cierta "hipótesis zombi" al discutir con el cognitivismo acerca del origen de la consciencia humana, dice que al final todos somos zombis, esa idea me tranquiliza un poco y a la vez me desposiciona, ¿seré el único en sentir con esta claridad sonámbula la zombificación a escala planetaria que padecemos?, he dejado de leer otras cosas, ciertas pesadillas me resultan amenazantes, lo raro es que nunca había sido fan de los zombis, los consideraba un elemento más de la cultura popular más comercial y fácil. Ahora es otra cosa. Esta cita del libro de Fernández Gonzalo me deja pensando durante días:

En cierto modo, el zombi quisiera borrar todas las historias del ser humano, todo su devenir histórico, y sobre ese espacio, obligarnos a una nueva vivencia del tiempo, a una visión no histórica de la realidad. Francis Fukuyama destruyó teórica y conceptualmente la era de la Historia, la versión histórica de nuestra experiencia vital. Los zombis, algo menos conceptuales, pero igual de decididos, creen que ese fin de la Historia pasa por alimentarse de todos los seres históricos que surgen a su paso. (Fernández, 2011, p. 201)

Apocalipsis zombi, parece ser un lugar común en esa clase de películas, un horizonte temporal borrado, luego de algún Armagedón de dimensiones planetarias o casi, la saga de Resident Evil mezcla todos esos temas de manera desmesurada. $\mathrm{Me}$ 
viene a la cabeza el motto de la película Contagio de Steven Soderberg [Warner Bros. Pictures, 2011]: "nada se contagia tanto como el miedo [nothing spreads like fear]". Lo cierto es que el paisaje posapocalíptico hace pensar en un tiempo vacío, nulo o seriamente trastornado, excelente motivo de un tempus ex machina como desgarro cronológico, como vivencia sin calendario en los albores del fin del mundo.

29.09.12. Zombies y parásitos. ¿Qué será una escritura parasitaria?, me encontré ayer un libro sobre Nietzsche con ese título (Mejía, 1996), rastreo por Internet y raros fragmentos aparecen vinculándolo con otros en los que se hace una especie de re-escritura espuria o imaginativa de autores reconocidos del canon literario. De nuevo la idea de remake. No puedo librarme de ella. Parece orientar el desarrollo ulterior de la escritura. La temporalidad del remake: una suerte de eterno retorno de relaboraciones siempre por comenzar.

Además, está el tema viral, definitivamente creo que una de las ideas que más me seduce, encantadora y siniestra, es la que vincula a los zombis con la idea de contagio descontrolado. La velocidad de propagación es la clave, el traslado de ideas o imágenes de una mente a otra, la imaginería zombi se ceba en tal horizonte, lo lleva al extremo, así los procesos de escritura desatados en esta tesis, deliberadamente exponiendo las referencias y las citas usadas como infección, como mezcla e hibridación con otros discursos en cuanto velocidades expresivas y semióticas que entran en conjunción extraña con ella. Relaciones o uniones "contra-natura" decían Deleuze y Guattari al hablar del Devenir animal. Revisar las mutaciones temporales que tal epidemia memética implica (me veo escribiendo las palabra parasito-mímesis, parasitómeme de forma involuntaria y repetitiva). (¿No?) Dejarse arrastrar (?) por esta frase del libro sobre escritura parasitaria: "aquí no se escribe sobre el parasitismo. Se parasita".

12.10.12. Estas últimas semanas la tesis y yo mismo hemos experimentado una cierta torsión metamórfica, la idea que me hago de ella, la idea que me asedia de ella, ella misma como un muerto-vivo. Por un lado, todo lo referido acerca del fantasma en el capítulo segundo podría pensarse desde la perspectiva zombi (me aterra la idea de que lo mismo ocurra con los restantes capítulos), es decir, la escritura histórica en ese estatuto indeciso entre presencia y ausencia, entre muerte y vida también, y sobre todo está el problema de los muertos, el maldito problema de los muertos, campo de reflexión específica del historiador, ¿hacer hablar a los muertos no es un problema de muertos vivientes acaso?, aquí se respira como un aire de cementerio, un hedor de cadáver redivivo o insuficientemente maquillado, no sé, una atmósfera de desborde semiótico quizá.

18.10.12. Abandono la idea de elaborar un capítulo sobre Zaratustra y los zombis, aprovecho un momento de lucidez y desisto, trato de borrar del computador los párrafos que había escrito en un estado semi-vigil y aturdido, sin embargo los temores vuelven, dudo mucho, la incertidumbre por momentos es inmanejable, escaneo del libro comic art now una imagen que juzgo interesante y la dejo como apertura de 
un posible epílogo que recoja los pedazos del diario que dan cuenta de esta fiebre pasajera (quién sabe si tenga efectos secundarios o reaparezca periódicamente, nerviosamente me digo que eso ya haterminado), son fragmentos inconexos en que la horda espectral trató de hacerse con el control de la tesis, produciendo una virosis gravísima, un estado de momentánea inconsciencia, y todo con el anhelo de que acabara pronto la pesadilla, como si escribir lo que me pasaba ayudara en algo, quién sabe, narrar cómo al final la peste fue rechazada (como una pirueta de la "profecía autocumplida"), exorcizada y confinada a un epílogo deshilachado casi como un cadáver andante, de donde espero que no vuelva a levantarse. 



\section{Conclusiones}

Oídas como diálogo (intermitente, perifrástico o enrollado) entre el Profesor Cascajo y Maese Periadoc (Personajes casi alter-egoicos en el batiburrillo de voces que merodearon la disolución del "autor").

Maese Periadoc (En lo sucesivo M.P.) (con aire metafísico, pero cruzado el ceño de una angustia escalofriante, ojos de encajado insomnio, pulso intranquilo). Me parece inevitable, a estas alturas de la tesis, referirme a la idea de obra "definitivamente inacabada", en el sentido que le dio Marcel Duchamp a su "Gran Vidrio", luego de trabajar en él por más de diez años.

Profesor Cascajo (en adelante P.C.) (Severo, imponente, siempre pensando en la rigurosidad de los lectores, jurados y otras figuras super-egoicas). Sería más pertinente, ordenado y claro puntualizar las ideas centrales de cada uno de los capítulos de la tesis.

M.P. (adoptando una postura conciliadora, pero sin traicionar su ánimo siempre polémico). Por supuesto, pero dejar de enfatizar el carácter infinitivo de la escritura en un trabajo sobre la idea de tiempo histórico en la obra de Nietzsche (suavizando el tono un tanto), dejaría un aire extraño en el documento, como de clausura interpretativa, de cierre epistemológico, una nube pesada de ideas supuestamente acabadas.

P.C. (sin prestar demasiada atención a las sutilezas gestuales de su interlocutor). Hablar de "nubes" en lugar de conceptos, seguir fascinado en preciosismos verbales en vez de ir directo a la idea me parece innecesario en este punto, la exploración sobre la filosofía de la temporalidad en la obra Así habló Zaratustra de F. Nietzsche; así como las reflexiones historiográficas concretas deben ser el objeto de las conclusiones (levantándose para señalar el inminente amanecer, hablando muy despacio). El capítulo final, el quinto, por ejemplo, me parece lo más logrado del documento, relacionando el pensamiento del eterno retorno con una temporalidad narrativa que en la escritura de la historia fabrica moldes cronológicos dados, de acuerdo a condiciones epistemológicas que deben ser explicitadas. 
M.P. (escuchando el canto apagado de los primeros pájaros). Sin embargo, profesor, hay que dar cuenta del ir y venir entre ese tipo de reflexiones y las imágenes que constelaron la narrativa, las referencias pictóricas, las derivas, los desvíos, las indecisiones y los apuntalamientos temáticos.

P.C. (Con el rostro más visible debido al sutil resplandor de la insinuada aurora, enérgico, como queriendo resolver rápido el acertijo). Eso es cierto, pero no lo es menos que hay una estructura disipativa que gobierna la narrativa de los argumentos expuestos en la tesis; en primer lugar, el origen del proyecto en un triple dominio expresivo, temporal y sensible (pensando en un imaginario cuadro explicativo de lo que acababa casi susurradamente de decir).

\section{M.P. (Impaciente) ¿Origen del proyecto?}

P.C. (Resuelto, proyectando la primera débil sombra sobre la orilla silueteada del lago). La idea de relacionar Así habló Zaratustra primero con la obra de Jacques Derrida "'; luego con los últimos seminarios de Foucault "“”) y finalmente, con Esferas de Peter Sloterdijk; esa era la intuición de arranque.

M.P. (Encontrando muy graciosa la alusión erudita a los textos y con los ojos clavados en la mirada de su contraparte). Intuición desbordada por la acción misma de "relacionar", que como un ritornelo reaparece en la tesis con expresiones como "poner en resonancia", "maridar", "conectar" y otras similares. En este caso, tal parentesco se da no solo con citas textuales de Así habló Zaratustra, los fragmentos póstumos o la correspondencia del periodo, sino también y de manera privilegiada con imágenes, pinturas, obras literarias e incluso, una pieza de música electrónica experimental (al decir esto empieza a sentir la necesidad de ponerse en el mismo nivel expresivo y bibliográficamente preciso que Cascajo, de momento, solo para burlarse).

P.C. (Sintiendo que por fin avanzan en la misma dirección, los contornos del paisaje influyendo la elección de palabras, impulsándolo a desarrollar sus ideas con más detalle). Cierto, allí donde esa resonancia tiene que ver con la imposibilidad de ubicar con precisión un término de la relación como "original" y otro como "copia", como si la distinción entre sentido propio (por ejemplo el pensamiento del eterno retorno) y sentido figurado (el monstruo o animal gigante que lo encarnaría ${ }^{1}$ ) se emborronara y de alguna forma los dos términos de la relación se indecidieran mutuamente, así las cosas, el pasaje metafórico de significado lograría que los dos elementos implicados por el deslizamiento tropológico perdieran su consustancialidad ontológica, como dice Slavoj Zizek en "The Parallax View": "Es por esto que el significado de una metáfora no puede reducirse a su "verdadera" referencia: no alcanza con señalar la realidad a la que refiere la metáfora; una vez realizada la sustitución metafórica, esta realidad queda habitada por el real

1 O su descripción como "pesadilla", "pasmo" o "visión extática”. 
espectral del contenido metafórico"2, o sea que cuando vemos (al sesgo, en paralaje) imágenes del Bosco, de William Blake o de Francis Bacon no se trata de meras ilustraciones subordinadas al sentido de aquella referencia en que se insertan (las voces internas de Nietzsche, su soledad como campo alquímico de transmutación o extrema experimentación ontológica, o la lógica paradójica del fantasma en la escritura de Así habló Zaratustra y del relato histórico, respectivamente), sino de espacios de resonancia que conectan campos de experiencia y formalizaciones discursivas heterogéneas, dispares, incluso incompatibles.

M.P. (Completamente maravillado por el despliegue discursivo de su interlocutor, fascinado por la cadencia danzarina de sus brazos al pronunciar las palabras, retado e interpelado, pero acusando cada vez más los efectos de la noche pasada en vela, simulando una voz cerebral). Aclarado y emborronado esto, mi tropológico e... (pronuncia esta palabra con sorna, entre irónico y admirado) indecidible profesor, no olvide que la ambigüedad de la voz "Fármakon", como la de "Fantasma", "Escritura" o "Temporalidad" fue el verdadero horizonte de los argumentos presentados (dice las palabras entre comillas en tono más alto y firme).

P.C. (Permanece en silencio, sumergido en sus pensamientos, entregado a la contemplación del sol que asoma sobrecogedoramente sobre el pico de las montañas).

M.P. (Para sus adentros, ignorando el gesto contemplativo de su interlocutor). La tesis partió de: un triple esquema visual, auditivo y olfativo para explorar, en síntesis, lo que llamaría una Crono-teratología espectroléptica de arke-sicofonías atmosismográficas ${ }^{3}$.

P.C. (De súbito volviendo a prestar atención a Periadoc) ¿Qué, quééé?

M.P. (Desentendido de todo, triunfante, Imagina el siguiente esquema).

Diagrama inicial de la tesis

\begin{tabular}{|l|l|l|l|l|l|}
\hline Capítulo & $\begin{array}{l}\text { Dominio } \\
\text { sensible }\end{array}$ & $\begin{array}{l}\text { Objeto de } \\
\text { análisis }\end{array}$ & $\begin{array}{l}\text { Autor } \\
\text { implicado }\end{array}$ & Obra escogida & Ideas centrales \\
\hline 1 & Ver & Animalazos & $\begin{array}{l}\text { Jacques } \\
\text { Derrida }\end{array}$ & $\begin{array}{l}\text { La bestia y el } \\
\text { soberano }\end{array}$ & $\begin{array}{l}\text { Animote, } \\
\text { devenir-animal }\end{array}$ \\
\hline
\end{tabular}

2 (Zizek, 2011, p. 205).

3 "Crono-teratología" por el prefijo "Cronos", tiempo y "teratología", ciencia o estudio de las monstruosidades o anomalías animales. "Espectro-léptica” con relación ya al segundo capítulo del documento (titulado "Soledumbre”), focalizado en la idea de "fantasma" o "espectro" y el sufijo "léptico" o "lepsis" como en la voz "epilepsia". "Arkesicofónica" como se explica en nota de pie de página al inicio del tercer capítulo, conectando el prefijo "Arkhe", antiguo, ancestral, pero también "poder" y "archivo" con el fenómeno de las sicofonías (percepción de voces fantasmales gracias a dispositivos electrónicos u otros). Por último, "atmo-sismográfico" según el capítulo cuarto de la tesis traza una relación de la construcción o elaboración de "atmósferas" y una pesquisa por los paisajes como modos históricamente dados de condensación de cierta idea de la espacialidad. 


\begin{tabular}{|l|l|l|l|l|l|}
\hline Capítulo & $\begin{array}{l}\text { Dominio } \\
\text { sensible }\end{array}$ & $\begin{array}{l}\text { Objeto de } \\
\text { análisis }\end{array}$ & $\begin{array}{l}\text { Autor } \\
\text { implicado }\end{array}$ & Obra escogida & Ideas centrales \\
\hline 2 & Oír & Voz espectral & $\begin{array}{l}\text { Michel } \\
\text { Foucault }\end{array}$ & $\begin{array}{l}\text { El gobierno de } \\
\text { síy de los otros }\end{array}$ & $\begin{array}{l}\text { Parrhesía, el } \\
\text { coraje de la } \\
\text { verdad. }\end{array}$ \\
\hline 3 & Oler & Air design & $\begin{array}{l}\text { Peter } \\
\text { Sloterdijk }\end{array}$ & Esferas & $\begin{array}{l}\text { Medioambiente } \\
\text { simbólico, } \\
\text { temporalidad y } \\
\text { meteorología }\end{array}$ \\
\hline
\end{tabular}

P.C. (Luego de un rato de estupefacción, sin saber si la luz declinante es ya la del mediodía o la insinuación de un anticipado crepúsculo, descifra las inscripciones y decide complementar el intento). Este primer esquema se complicó ya que luego del primer capítulo se hizo imperativo la inclusión de un campo de reflexión específico para conectar e hibridar Así habló Zaratustra con las consideraciones del segundo tomo de La bestia y el soberano de Jacques Derrida, dedicado enteramente a la tematización de la "soledad" (visualizando mentalmente una suerte de artefacto pentadimensional que sería la tesis misma, supersimétrico y transparente, quizá fractal), por ello apareció un segundo capítulo dedicado a la experiencia de la soledad, tanto en Nietzsche como autor de su obra como de su personaje Zaratustra, en tal sentido cada uno de los tres primeros capítulos se desdobló como se aprecia en un segundo cuadro analítico (desconociendo el soporte de inscripción del diagrama, así como el tiempo requerido para su elaboración y enunciación).

Diagrama expandido de la tesis

\begin{tabular}{|c|c|c|c|c|c|}
\hline Capítulo inicial & $\begin{array}{l}\text { Resonancias } \\
\text { temáticas } \\
\text { adicionadas }\end{array}$ & Imágenes usadas & $\begin{array}{l}\text { Bibliografía } \\
\text { añadida }\end{array}$ & $\begin{array}{l}\text { Capítulo } \\
\text { adicionado }\end{array}$ & $\begin{array}{l}\text { Característica } \\
\text { medular }\end{array}$ \\
\hline $\begin{array}{l}\text { 1. Bestias y } \\
\text { super-dragones } \\
\text { (Cronoteratología) }\end{array}$ & $\begin{array}{l}\text { Soledumbre, } \\
\text { espectros y } \\
\text { fantasmas }\end{array}$ & $\begin{array}{l}\text { 1. Ilustraciones de } \\
\text { William Blake } \\
\text { 2. Pinturas de } \\
\text { Francis Bacon } \\
\text { 3. Alegorías } \\
\text { alquímicas }\end{array}$ & $\begin{array}{l}\text { Correspondencia } \\
\text { de Nietzsche }\end{array}$ & 2. Soledumbre & Espectrolepsis \\
\hline $\begin{array}{l}\text { 2. Voces interiores } \\
\text { y parrhesía } \\
\text { (Foucault) }\end{array}$ & $\begin{array}{l}\text { Realidad } \\
\text { Daimónica, } \\
\text { parásitos } \\
\text { mentales }\end{array}$ & $\begin{array}{l}\text { Imaginería del } \\
\text { Bosco (Jeronimus } \\
\text { Bosch) } \\
\text { Pintura surrealista } \\
\text { (Max Ernst) } \\
\text { Arte dadaísta } \\
\text { (Switters) }\end{array}$ & $\begin{array}{l}\text { Relatos de Edgar } \\
\text { Allan Poe y J. L. } \\
\text { Borges. } \\
\text { Textos de Carlos } \\
\text { Castaneda } \\
\text { Fragmentos de } \\
\text { W. B. Yeats }\end{array}$ & & Arke-sicofonía \\
\hline
\end{tabular}




\begin{tabular}{|l|l|l|l|l|l|}
\hline Capítulo inicial & $\begin{array}{l}\text { Resonancias } \\
\text { temáticas } \\
\text { adicionadas }\end{array}$ & Imágenes usadas & $\begin{array}{l}\text { Bibliografía } \\
\text { añadida }\end{array}$ & $\begin{array}{l}\text { Capítulo } \\
\text { adicionado }\end{array}$ & $\begin{array}{l}\text { Característica } \\
\text { medular }\end{array}$ \\
\hline $\begin{array}{l}\text { 3. Esferas y } \\
\text { espaciogénesis } \\
\text { (Sloterdijk con } \\
\text { Zaratustra) }\end{array}$ & $\begin{array}{l}\text { Construcción } \\
\text { de la } \\
\text { temporalidad } \\
\text { yescritura de } \\
\text { la historia }\end{array}$ & $\begin{array}{l}\text { Grabados de } \\
\text { G. Piranesi, } \\
\text { fotogramas de } \\
\text { 2001: Odisea del } \\
\text { Espacio, escultura } \\
\text { minimalista. }\end{array}$ & $\begin{array}{l}\text { Metahistoria, } \\
\text { Historia y } \\
\text { Tropología, Mil } \\
\text { Mesetas. }\end{array}$ & $\begin{array}{l}\text { Historiografía } \\
\text { yeoría de la } \\
\text { Historia }\end{array}$ & $\begin{array}{l}\text { Atmo- } \\
\text { sismografía }\end{array}$ \\
\hline
\end{tabular}

M.P. (Ensoñativo, como en un fotograma de tiempo suspendido, hierático, dubitativo y concluyente en el mismo desmedido momento). Ahora entiendo, así las cosas y dada la rigurosidad en el armado del diagrama, se me ocurre que la conclusión conceptual solo podría ser enunciada como narrativa de los eventos discursivos de la tesis misma (como quitándose un peso de encima), la conclusión, la conclusión al fin.

P.C. (Sin temor al reinicio infinito del relapso crónico que vivían, ni al hilado en loop de alguna jugarreta del eterno retorno, más bien melancólico, acorralado por sus propios insustanciales pensamientos). Por favor, maese, la conclusión como quieras pero entendible (regresando imperceptiblemente a su postura inicial sobre la claridad y el eslabonamiento lógico de los conceptos, definiciones y argumentos).

M.P. (Apodíctico y sombrío, febril, traspasado por un espasmo de frío inaudito). Primero, aclaramos que hay cuatro excursos perfectamente prescindibles, que tratan de puntuar desde una cierta poética de la aliteración y el ritornelo, la idea de una temporalidad y una narrativa histórica alternativa. Se encabalgan como paréntesis para-sintácticos por su naturaleza accesoria quizá significativos, fueron tal vez los segmentos más trabajados de toda la tesis, posibles líneas de fuga en tono deliberadamente experimental, patafísico-escurridizo y sinuoso (entre lo anterior y el último segmento se filtra como un temblor, un prurito de voz extasiada, como si alguien más estuviera diciendo el relato), bajo la sombra del temible Jabberwocky, el primer capítulo esquivó las garras de cinco grandes bestias que aparecen en la obra Así habló Zaratustra de Nietzsche, al inicio se reseñó el encuentro de Zaratustra con sus animales alegóricos (el águila y la serpiente) los cuales lo aconsejaron respecto a su simbolismo e importancia, problematizando la distinción entre "humano" y "animal", entre tanto, como adelantamos, el relato se enfrentó a cinco figuras temibles: el Gran Dragón, el más frío de todos los monstruos fríos, el superdragón (como presa del super-hombre), el eterno retorno como ciclópeo gusano o gran animal de pesadilla, y finalmente el enigmático "animal interior".

De esta lucha o combate iniciático, en resonancia con ideas de Derrida en su seminario La bestia y el soberano, el análisis de Zaratustra entró en devenir con la obra del pintor y escritor inglés William Blake. Soportando así una experiencia de soledad transmutadora tanto la figura de Zaratustra como la del mismo Nietzsche. 
Encontrándose ambos en tal estado de angustia y abandono se toparon con los "cuerpos sin órganos" del pintor irlandés Francis Bacon, en cuanto espectros de dudosa adscripción ontológica, estos rostros monstruosos permitieron hacer referencias no solo a cinco momentos privilegiados del recorrido "solitario" de Zaratustra, sino a consideraciones específicas sobre la escritura de la historia, la insistencia de las voces del pasado y la soledumbre como instancia de transformación identitaria (y temporal) privilegiada.

Voces desmaterializadas y obsesivas cernidas sobre la figura de San Antonio conectaron las ideas anteriores con una reflexión sobre "la más silenciosa de todas las Horas" en Así habló Zaratustra, la narrativa en este capítulo se dejó encantar por el fenómeno de la voz electrónica (EVP, por sus iniciales en inglés), es decir, se escenificó aquí el combate de voces o parásitos mentales en el autor de Así habló Zaratustra, corporeizados en figuras horripilantes y caras desfiguradas. Detalles de la tabla derecha o "infierno musical" entre otras pinturas de Jerónimo Bosco, ritmaron la aparición de ideas sobre la escritura de la historia. Un lugar privilegiado lo ocupó alguna reflexión sobre el silencio y la cesación del flujo de la temporalidad (John Cage, Carlos Castaneda, Borges, Edgar Allan Poe, W. B. Yeats).

El capítulo termina con la aparición de la idea de parrhesía que Foucault analiza en la tragedia griega y la antigüedad clásica, una forma de hablar que implica la destrucción valerosa del sujeto de enunciación, una forma dramática y particularmente agonística de generación de discursos con valor de verdad.

Enseguida y entrando en un laberíntico espacio de resonancia, las cárceles de Giovanni Piranesi ambientan la apertura a ciertas "esferas" de Peter Sloterdijk, burbujas, globos y espumas de espacialidad autogenerada, por ello, se partió de la proyectada introducción de Sloterdijk al "nacimiento de la tragedia" de Nietzsche, justamente para acompañar este descenso casi infernal al estado climático y anímico que determinó la escritura de Así habló Zaratustra. A partir de esta sospecha se adelantó una hipótesis "atmo-terrorista", según califica el filósofo de Karlsruhe las nuevas modalidades de aniquilación del enemigo (a finales del siglo XIX y a lo largo del siglo XX). Cierta bruma de suspicacia paranoide permanece sin disiparse a medida que avanza el capítulo. Sobre esto, nuevamente, como en el capítulo sobre la soledad, la correspondencia de Nietzsche en el periodo de escritura de Así habló Zaratustra se revela clave, lo cual permite desnudar una suerte de conspiración atmosférica que habría encontrado en el mismo Friedrich Nietzsche una víctima propiciatoria.

La línea argumentativa se permite mezclas y superposiciones con composiciones de música electrónica como la pieza "Friedrich Nietzsche" de Klaus Schulze, en un momento en el que la alegoría sonora teje un receptáculo perceptivo que intenta salirse de la línea causal de encadenamiento de los acontecimientos, un espasmo a-crónico en el que (como se desplegará en el último capítulo) se vislumbre el resplandor unheimlich del Acontecimiento, del Aión como modo de temporalidad 
impredecible e intensivo. Justo aquí se vierte la anestesia estética (reducción formal y sobriedad extrema) propia del arte minimalista del siglo XX al tomar como metáfora axial el monolito que aparece en la novela del escritor de ciencia ficción Arthur C. Clarke 2001: Odisea del Espacio (escrita concomitantemente con el guión de la película del mismo nombre dirigida por Stanley Kubrick), en cuanto representación de las "tablas valorativas" que Zaratustra instiga incesantemente a romper.

La sucesión narrativa oscila entre los simios pre-homínidos de hace millones de años, la genealogía nietzscheana de valores históricamente asfixiantes y las visiones de una narrativa en shock temporal, convulsionada o suspendida infinitamente como la experimentada al final de la película 2001: Odisea del Espacio.

Como una emanación en tono ensayístico, menos cargada de metáforas, el quinto y último capítulo encuentra otra ruta enunciativa y traza un paralelo entre la filosofía narrativista de la historia ejemplificada en la obra de Hayden White y F. Ankersmit con estudios sobre la idea de Historia y temporalidad en el pensamiento de F. Nietzsche, sin embargo, se apela a estudios específicos sobre Así habló Zaratustra que no dejan de generar perplejidad incluso en medio del tono académico más impersonal y desapasionado. Al final la tesis se cierra con consideraciones específicas sobre el concepto de tiempo histórico y el quehacer del historiador, se conjuran los monstruos, los parásitos y los espectros, las parálisis crónicas y los ritornelos a Mnemosyne, las caídas de cabeza, los laberintos y las miradas, las voces duales intersecadas y difractantes, aparece la idea de devenir y la provocadora o polémica idea de una des-construcción o transmutación de la idea moderna de "tiempo histórico". 



\section{Referencias}

Agamben, G. (2005). Lo Abierto, El hombre y el animal. Valencia: Pre-textos.

Angulo, E. (2007). Monstruos, una visión científica de la criptozoología. Madrid: 451 editores.

Ankersmit, F. R. (2004). Historia y Tropología, Ascenso y caída de la metáfora. México: Fondo de Cultura Económica.

Baring, A. y Cashford, J. (2005). El mito de la Diosa, evolución de una imagen. México: Siruela/Fondo de Cultura Económica.

Berkowitz, P. (2000). Nietzsche, la ética de un inmoralista. Madrid: Siruela/Fondo de Cultura Económica.

Blake, W. (1998). Antología: Madrid: Alianza.

Blake, W. (2013). Libros Proféticos. Tomo I. Girona: Atalanta.

Blake, W. (2014). Libros Proféticos. Tomo II. Girona: Atalanta.

Borges, J. L. (1989a). Obras Completas, Tomo I. Barcelona: Emecé.

Borges, J. L. (1989b). Obras Completas, Tomo III. Barcelona: Emecé.

Bosing, W. (2007). El Bosco. Köln: Taschen.

Breisach, E. (2009). Sobre el futuro de la historia, el desafío posmodernista y sus consecuencias. Valencia: P. U. V.

Brobjer, T. (2004). Nietzsche's View of the Value of Historical Studies and Methods. Journal of History of Ideas, 65(2), 301-322.

Brobjer, T. (2007). Nietzsche's Relation to Historical Methods and nineteenth-century German Historiography. History and Theory, 46(2), 155-179.

Burke, P. (1999). La revolución historiográfica francesa: la Escuela de los Annales (1929-1989). Barcelona: Gedisa.

Carpentier, A. (1994). El reino de este mundo. Barcelona: Seix Barral.

Carroll, L. (1997). Alicia a través del espejo. (Trad. Jaime de Ojeda). Madrid: Alianza.

Carroll, L. (2010). Los libros de Alicia. Buenos Aires: Ediciones de la Flor

Carroll, L. (2012). Alice's Adventures in Wonderland \& Through the looking-Glass. New York: Signet Classics.

Castaneda, C. (1972). Journey to Ixtlan. New York: Simon and Schuster.

Castaneda, C. (1977). Viaje a Ixtlán. México: Fondo de Cultura Económica. 
Castaneda, C. (2000). El lado activo del infinito. Madrid: Biblioteca de Bolsillo.

Chion, M. (1999). El sonido, música, cine, literatura. Barcelona: Paidós.

Cioran, E. M. (2009). Adiós a la filosofía y otros textos. Madrid: Alianza.

Clarke, A. C. (1977). 2001 Una Odisea del Espacio. Buenos Aires: Pomaire.

Conil, J. (1988). El crepúsculo de la Metafísica. Barcelona: Anthropos.

Corbin, A. (2002). El perfume o el miasma. El olfato y lo imaginario social. Siglos XVIII y XIX. México: Fondo de Cultura Económica.

Cragnolini, M. (2010a). De otro modo de ser: el animal nietzscheano. Aportes para la cuestión de la biopolítica. Santiago de Chile: Universidad Diego Portales.

Cragnolini, M. (2010b). Extraños devenires: una indagación en torno a la problemática de la animalidad en la filosofía nietzscheana. Revista Instantes y Azares. Escrituras nietzscheanas, 8, 13-30.

De Givry, G. (1971). Witchcraft, Magic \& Alchemy. New York: Dover Publications.

De Greiff, L. (2004). Obra Poética. Vol. 3. 1954-1972. Bogotá: Universidad Nacional de Colombia.

De la Cruz, J. I. (1994). Obra selecta, Tomo II. Caracas: Biblioteca Ayacucho.

Deleuze, G. y Guattari, F. (1997). Mil Mesetas, Capitalismo y Esquizofrenia. Valencia: Pre-textos.

Derrida, J. (2008). El animal que luego estoy si(gui)endo. Madrid: Trotta.

Derrida, J. (2008b). Séminaire La bête et le souverain, Volume I (2001-2002). Paris: Galilée.

Derrida, J. (2009). Otobiografías, La enseñanza de Nietzsche y la política del nombre propio. Buenos Aires: Amorrortu.

Derrida, J. (2010). Seminario La bestia y el soberano, Volumen I (2001- 2002). Buenos Aires: Manantial.

Derrida, J. (2011). Seminario La bestia y el soberano, Volumen II (2002- 2003). Buenos Aires: Manantial.

Didi-Huberman, G. (1997). Lo que vemos, lo que nos mira. Buenos Aires: Manantial.

Distin, K. (2005). El meme egoísta. Barcelona: Biblioteca Buridán.

Dosse, F. (2009). Gilles Deleuze y Félix Guattari, Biografía Cruzada. México: Fondo de Cultura Económica.

Dries, M. (Ed.) (2008). Nietzsche on time and history. Berlin: Walter de Gruyter. 
Elger, D. (2004). Dadaísmo. Köln: Taschen.

Ende, M. (2006). La historia interminable. Madrid: Santillana- Punto de lectura.

Ermarth Deeds E. (2011). History in the discursive condition, reconsidering the tools of thought. London: Routledge.

Ermarth Deeds, E. (1992). Sequel to history. Postmodernism and the crisis of representational time. Pinceton: Princeton University Press.

Ermarth Deeds, E. (2011). "The future of history" by Alan Munslow a Review. Recuperado en http://www.history.ac.uk/review/1220.

Ernst, B. (2007). El espejo mágico de M. C. Escher. Köln: Taschen.

Ernst, M. (2008). Tres novelas en imágenes. Girona: Atalanta.

Fernández Gonzalo, J. (2011). Filosofía Zombi. Barcelona: Anagrama.

Fernández Porta, E. (2010). Homo Sampler, Tiempo y consumo en la era afterpop. Barcelona: Anagrama.

Ficacci, L. (2010). Francis Bacon. Köln: Taschen.

Ficacci, L. (2011). Piranesi T.I. Köln: Taschen.

Foucault, M. (1979). Microfísica del poder. Madrid: La Piqueta.

Foucault, M. (1996). Tecnologías del yo. Barcelona: Paidós.

Foucault, M. (1997). La arqueología del saber. México: Siglo XXI.

Foucault, M. (2004). La Hermenéutica del sujeto. México: Fondo de Cultura Económica.

Foucault, M. (2008). Nietzsche, la Genealogía, la Historia. Valencia: Pre-textos.

Foucault, M. (2009). El gobierno de sí y de los otros. México: Fondo de Cultura Económica.

Foucault, M. (2010). El coraje de la verdad. México: Fondo de Cultura Económica.

Getty, A. (1996). La Diosa, Madre de la naturaleza viviente. Madrid: Debate.

Gomez, T. (2003). Lovecraft, la Antología. Barcelona: Océano.

Grant, G. (1995). Time and History. Toronto: University of Toronto Press.

Grossato, A. (2000). El libro de los símbolos, Metamorfosis de lo humano entre oriente y occidente. Barcelona: Grijalbo.

Hayman, R. (1998). Nietzsche, las voces de Nietzsche. Bogotá: Norma.

Harpur, P. (2007). Realidad Daimónica, Atalanta, Girona. 
Jenkins, K. (2006). ¿Por qué la Historia? México: Fondo de Cultura Económica.

Joutard, P. (1999). Esas voces que nos llegan del pasado. México: Fondo de Cultura Económica.

Jung, C. G. (2005). Psicología y alquimia, Obra completa Vol.12. Madrid: Trotta.

Lipovetsky, G. y Serroy, J. (2015). La estetización del mundo. Vivir en la época del capitalismo artístico. Barcelona: Anagrama.

Loeb, P. (2010). The death of Nietzsche's Zarathustra. Cambridge: Cambridge University Press.

Lotman, I. (2000). La Semiosfera, Semiótica de la Cultura. Madrid: Frónesis-Cátedra.

Lovecraft, H. P. (1997). Los Mitos de Cthulhu. Madrid: Alianza.

Maclagan, D. (1994). Mitos de la Creación, la aparición del hombre en el mundo. Madrid: Debate.

Maier, M. (2007). La Fuga de Atalanta. Girona: Atalanta.

Martorell, J. (1997). La Voz del Desierto: El legado espiritual de los eremitas cristianos. Madrid: Edaf.

Marzona, D. (2004). Arte minimalista. Köln: Taschen.

Mazzoldi, B. (2011). Variaciones alrededor de un mal de cabeza. Revista Instantes y Azares, Escrituras nietzscheanas, XI(9), 52-68.

Mejía, J. M. (1996). De la escritura parasitaria, Nietzsche, Kafka, Deleuze, Dostoievski. Medellín: Universidad de Antioquia.

Meyer, J. (2011). Arte minimalista. Londres: Phaidon.

Morin, E. (1998). El Método tomo IV, Las ideas, su hábitat, su vida, sus costumbres, su organización. Madrid: Cátedra.

Munslow, A. (1997). Deconstructing history. London-NY: Routledge.

Nietzsche, F. (1927). Also Sprach Zarathustra. Leipzig: Alfred Kröner Verlag.

Nietzsche, F. (1965). Obras Completas, Tomo III. (Trad. Eduardo Ovejero y Maury). Buenos Aires: Aguilar.

Nietzsche, F. (1969). Thus Spoke Zarathustra. (Trad. R. J. Hollingdale). New York: Penguin Classics.

Nietzsche, F. (1995). Ecce Homo. (Trad. Andrés Sánchez Pascual). Madrid: Alianza.

Nietzsche, F. (1995). La Genealogía de la Moral. Madrid: Alianza.

Nietzsche, F. (2000). Sobre la utilidad y los perjuicios de la historia para la vida. Madrid: Edaf. 
Nietzsche, F. (2000b). El Anticristo, maldición sobre el cristianismo. (Trad. Germán Cano). Madrid: Biblioteca Nueva.

Nietzsche, F. (2002). El caso Wagner / Nietzsche contra Wagner. Madrid: Siruela.

Nietzsche, F. (2003). Más allá del bien y del mal. (Trad. Andrés Sánchez Pascual). Madrid: Alianza.

Nietzsche, F. (2004). Así hablaba Zaratustra. México: Porrúa.

Nietzsche, F. (2006). Así habló Zaratustra. (Trad. Andrés Sánchez Pascual). Madrid: Alianza.

Nietzsche, F. (2006b). La hora del gran desprecio. Fragmentos póstumos (Otoño, 1882-Verano, 1883). Madrid: Biblioteca Nueva.

Nietzsche, F. (2008). Sobre verdad y mentira. Madrid: Tecnos.

Nietzsche, F. (2008). Fragmentos póstumos (1885-1889) Vol. IV. Madrid: Tecnos.

Nietzsche, F. (2008b). Poesía Completa. (Trad. Laureano Pérez Latorre). Madrid: Trotta.

Nietzsche, F. (2010b). Así habló Zaratustra. (Trad. Luis A. Acosta). Madrid: Cátedra.

Nietzsche, F. (2010). Correspondencia vol. IV, enero 1880- diciembre 1884. Madrid: Trotta.

Nietzsche, F. (2011). Así habló Zaratustra, el Manga. Barcelona: Herder.

Nietzsche F. (2012). Así habló Zaratustra, el manga. Barcelona: Herder.

Paez A., Ataefe, S.y Moreno H. (2002). Tratado Universal de Dragones. Barcelona: Círculo Latino.

Perera, V. (2012). Fuga Animal, Atlas zoopolítico. Madrid: Dykinson.

Pletsch, C. E. (1977). History and Friedrich Nietzsche's philosophy of time. History and Theory, 16(1), 31-39.

Poe, E. A. (2009). The collected tales and poems. London: Wordsworth library collection.

Poe, E. A. (2010). Cuentos 1. (Trad. Julio Cortázar). Madrid: Alianza.

Roob, A. (1997). Alquimia y Mística, el Museo Hermético. Köln: Taschen.

Rosen, S. (1995). The mask of enlightenment: Nietzsche's Zarathustra. Cambdridge: Cambridge University Press.

Ross, W. (1994). El Águila angustiada. Barcelona: Paidós.

Ruiz, M. (2004). La voz del conocimiento. Barcelona: Urano.

Sábato, E. (1992). Abaddón el exterminador. Barcelona: Seix-Barral.

Safranski, R. (2009). Nietzsche, Biografía de su pensamiento. Barcelona: Tusquets.

Seung, T. (2005). Nietzsche's epic of the soul: Thus Spoke Zarathustra. Oxford: Lexington Books. 
Shuker, K. (2006). Dragones, una historia ilustrada. Köln: Evergreen/Taschen.

Skinn, D. (2009). Comic art now, Ilustración de cómic contemporánea. Barcelona: Ed. Gustavo Gil.

Sloterdijk, P. (2000). El pensador en escena. El materialismo de Nietzsche. Valencia: Pre-textos.

Sloterdijk, P. (2004). Esferas II (Globos). Madrid: Debate.

Sloterdijk, P. (2009). Esferas I (Burbujas). Madrid: Siruela.

Sloterdijk, P. (2009b). Esferas III (Espumas). Madrid: Siruela.

Small, R. (2010). Time and becoming in Nietzsche's thought. London: Continuum studies in Continental Philosophy.

Soler, C. (2007). Declinaciones de la angustia. Bogotá: Ánfora.

Stiegler, B. (2003). Aimer, s'aimer, nous aimer. París: Galilée.

Süskind, P. (2010). El Perfume, historia de un asesino. Bogotá: Seix Barral-Planeta.

Torrano, A. Ontologías de la Monstruosidad: el cyborg y el monstruo biopolítico. Recuperado de www.publicaciones.ffyh.unc.edu.ar/index.pnp/6encuentro/ article/viewfile/62.

Tsutsui, Y. (2011). Paprika. Girona: Atalanta.

Turpin, I. (1979). Max Ernst. Edinburgh: Phaidon.

Vélez, M. C. (2004). Las vírgenes energúmenas. Medellín: Universidad de Antioquia.

Von Franz, M. L. (1996). Misterios del Tiempo. Madrid: Debate.

Wells, H.G (2012). La Máquina del Tiempo. México: Porrúa.

White, H. (1992). El contenido de la forma, Narrativa, discurso y representación histórica. Barcelona: Paidós.

White, H. (2001). Metahistoria, La imaginación histórica en la Europa del siglo XIX. México: Fondo de Cultura Económica.

Winders, J. A. (1993). "Narratime": Postmodern Temporality and Narrative. Issues in integrative Studies, 11, 27-43.

Wood, D. (2001). The Deconstruction of time. Illinois: Northwestern University Press.

Yeats, W. B. (1992). Rosa alquímica. Madrid: Mondadori.

Zizek, S. (2002). Mirando al sesgo. Barcelona: Paidós.

Zweig, S. (1934). La lucha contra el demonio, Hölderlin, Kleist, Nietzsche. Barcelona: Apolo. 

Esta obra se editó en Ediciones USTA, Departamento Editorial de la Universidad Santo Tomás. Se usó cartón de baja densdad de 280 gramos para la carátula y papel bond beige de 70 gramos para páginas internas. Tipografía: Minion Pro. Impreso por Image Printing Ltda. 
Un fantasma asedia el relato histórico, un indecible espectro quiere exorcizarse sin fin en las páginas de este libro. Encantada así por la relación entre poética de la historia, pintura, cine y vértigo de la temporalidad en Así habló Zaratustra de Friedrich Nietzsche, la escritura de esta obra explora los regímenes narrati-vos de la historiografía contemporánea a partir de ideas de Michel Foucault, Jacques Derrida y Peter Sloterdijk en un conjunto abierto de alusiones inacabadas. En el corazón tenebroso del libro late una fascinación por los desvíos a la linealidad cronológica derivada de la epistemología de la modernidad. De allí que Tempus ex Machina sea tanto un artificio para poner en paréntesis tales compulsiones interpretativas, como un salto al abismo frente a esta forma de concebir la narrativa del relato histórico. 